\title{
Formulation, process conditions, and biological evaluation of dairy mixed gels containing fava bean and milk proteins: Effect on protein retention in growing young rats
}

\author{
I. Berrazaga, ${ }^{1,2 *}$ J. L. Mession, ${ }^{3 *}$ K. Laleg, ${ }^{1}$ J. Salles, ${ }^{1}$ C. Guillet, ${ }^{1}$ V. Patrac, ${ }^{1}$ C. Giraudet, ${ }^{1}$ O. Le Bacquer, ${ }^{1}$ \\ Y. Boirie, ${ }^{1,4}$ V. Micard, ${ }^{2}$ F. Husson, ${ }^{3}$ R. Saurel, ${ }^{3}$ and S. Walrand ${ }^{1} \dagger$ \\ ${ }^{1} \mathrm{UNH}$, Unité de Nutrition Humaine, CRNH, Université Clermont Auvergne, INRA, Auvergne, 63000 Clermont-Ferrand, France \\ ${ }^{2}$ Unité Mixte de Recherche (UMR), IATE Agropolymers Engineering and Emerging Technologies, Université Montpellier, Montpellier SupAgro, \\ INRA, CIRAD, 34060 Montpellier, France \\ ${ }^{3}$ UMR Procédés Alimentaires et Microbiologiques, Agrosup Dijon, Université de Bourgogne Franche-Comté, 21000 Dijon, France \\ ${ }^{4}$ Service de Nutrition Clinique, Centre Hospitalier Universitaire (CHU) Gabriel Montpied, 63000 Clermont-Ferrand, France
}

\section{ABSTRACT}

Food formulation and process conditions can indirectly influence AA digestibility and bioavailability. Here we investigated the effects of formulation and process conditions used in the manufacture of novel blended dairy gels (called "mixed gels" here) containing fava bean (Vicia faba) globular proteins on both protein composition and metabolism when given to young rats. Three mixed dairy gels containing casein micelles and fava bean proteins were produced either by chemical acidification (A) with glucono- $\delta$-lactone (GDL) or by lactic acid fermentation. Fermented gels containing casein and fava bean proteins were produced without $(\mathrm{F})$ or with (FW) whey proteins. The AA composition of mixed gels was evaluated. The electrophoretic patterns of mixed protein gels analyzed by densitometry evidenced heat denaturation and aggregation via disulfide bonds of fava bean 11S legumin that could aggregate upon heating of the mixtures before gelation. Moreover, fermented gels showed no particular protein proteolysis compared with gel obtained by GDL-induced acidification. Kinetics of acidification were also evaluated. The $\mathrm{pH}$ decreased rapidly during gelation of GDL-induced acid gel compared with fermented gel. Freeze-dried F, $\mathrm{A}$, and FW mixed gels were then fed to 30 young ( 1 mo old) male Wistar rats for $21 \mathrm{~d}(\mathrm{n}=10 /$ diet $)$. Fermented mixed gels significantly increased protein efficiency ratio $(+58 \%)$ and lean mass $(+26 \%)$, particularly muscle mass $(+9 \%)$, and muscle protein content $(+15 \%)$ compared with GDL-induced acid gel. Furthermore, F and

Received February 19, 2018.

Accepted September 25, 2018.

*These authors contributed equally to this study.

†Corresponding author: stephane.walrand@inra.fr
FW formulas led to significantly higher apparent digestibility and true digestibility $(+7 \%)$ than A formula. Blending fava bean, casein, and whey proteins in the fermented gel FW resulted in 10\% higher leucine content and significantly higher protein retention in young rats $(+7 \%$ and $+28 \%)$ than the $\mathrm{F}$ and $\mathrm{A}$ mixed gels, respectively. Based on protein gain in young rats, the fermented fava bean, casein, and whey mixed proteins gel was the most promising candidate for further development of mixed protein gels with enhanced nutritional benefits.

Key words: dietary protein quality, protein aggregation, fava bean protein, milk protein, gelation

\section{INTRODUCTION}

Promoting vegetable protein sources in human food intake can help efforts to prevent health risks associated with an excessive consumption of animal-based foodstuffs and reduce the ecological footprint of animal production (Duranti and Scarafoni, 1999; FAO, 2013). However, vegetable proteins such as legume proteins are deficient in some essential AA (i.e., sulfur AA; Boye et al., 2010). This deficiency could be resolved by mixing animal and legume protein sources. Owing to their wide consumption and appreciation, dairy-based gel products are appropriate for this novel association. In particular, yogurt-like products display both high sensory preference and satisfying nutritional value regarding essential AA and minerals in organic form easily assimilated by the organism (Cayot and Lorient, 1998; Sfakianakis and Tzia, 2014). Dairy gels such as yogurt are manufactured from milk, and their gel structure results from the coagulation of milk proteins (Chandan, 2006). Acid gelation of milk can be achieved by fermentation using lactic acid bacteria or chemically using organic acids such as glucono- $\delta$-lactone (GDL; 
Lucey et al., 1998). Moreover, versatility of the different dairy protein fractions regarding their functional properties would allow their incorporation in a wide range of textured food stuffs, alone or with other protein sources (Cayot and Lorient, 1998).

Several studies have evaluated and compared the physicochemical properties, including rheological behavior, of dairy gels produced by fermentation and chemical acidification (Amice-Quemeneur et al., 1995; Vlahopoulou and Bell, 1995; Lucey et al., 1998; Laligant et al., 2003; Azim et al., 2010). Authors have studied the effect of mixing milk proteins with legume proteins (i.e., pea, soy, or lentil; Zare et al., 2011, 2012a,b; Beliciu and Moraru, 2013; Wong et al., 2013; Yousseef et al., 2016; Akin and Ozcan, 2017). Interactions between the 2 protein sources in admixture and the formation of aggregates during thermal processing were also investigated (Roesch and Corredig, 2005, 2006; Chihi et al., 2016; Mession et al., 2017a,b). It was reported that fermentation of milk, legume flour, or legume-enriched products could improve their protein efficiency ratio and in vivo and in vitro protein digestibility compared with nonfermented products (Lee et al., 1988; Torres et al., 2006; Chandra-Hioe et al., 2016; Rizzello et al., 2017). However, to our knowledge, the influence of both formulation and process conditions (heating and gelation route) of legume-dairy mixed gels on their nutritional properties has not yet been studied.

In this study, dairy gels were enriched with fava bean proteins to improve the nutritional value of legume proteins. The objective was to evaluate the effects of formulation and process on protein composition of the fava bean-dairy mixed gels and their assimilation in young rats.

For this purpose, cow milk proteins (casein micelles and whey proteins) and fava bean proteins were laboratory-prepared and characterized separately in terms of composition. Fava bean-dairy mixed gels containing $53 \pm 1 \%$ fava bean proteins and $47 \pm 0.5 \%$ total milk proteins were then manufactured. This composition was established on the basis of a typical dairy yogurt containing approximately $40 \mathrm{~g}$ of protein $/ \mathrm{kg}$ (Favier, 1987), from which protein content was supplemented 2 -fold with legume proteins. Different protein mixtures were prepared and coheated to induce protein thermal denaturation and aggregation to enhance protein gelation abilities (Chihi et al., 2016). Gelation of coheated mixtures was subsequently performed by 2 different processes: chemical acidification with GDL or lactic acid fermentation. Protein efficiency, protein digestibility, protein retention, and growth rate were evaluated in young rats fed the freeze-dried and crushed fava bean-dairy mixed gels for $21 \mathrm{~d}$ to determine the most promising mixed gel formula in terms of nutritional enhancement.

\section{MATERIALS AND METHODS}

\section{Raw Materials}

The globular fava bean proteins were extracted from an air-classified concentrate supplied by Sotexpro (La Croix Forzy, Bermericourt, France). Fat and CP contents were 8.6 and $58.2 \%$ by weight on a DM basis, respectively. Whey protein (Promilk 802 FB) and casein (MPC 852B) commercial isolates were supplied by Ingredia (Arras, France). Total protein content was $77.8 \%$ by weight for whey and $83.0 \%$ by weight on a DM basis for casein raw materials. A commercial freeze-dried lactic bacteria cocktail (Streptococcus thermophilus and Lactobacillus delbrueckii ssp. bulgaricus) was purchased in a local supermarket (Alsa, Rueil Malmaison, France). All other reagents and chemicals purchased from Sigma-Aldrich (St Louis, MO) were of analytical grade.

\section{Chemical Assays}

Total moisture and ash content were evaluated according to AOAC International (1995) procedures. Protein nitrogen was determined according to EN ISO 20483:2013 method (ISO, 2013), with a nitrogen-to-protein conversion factor of 6.25 for fava bean proteins and 6.38 for milk proteins. Reducing sugar (lactose) content of milk samples was assessed using 3,5-dinitrosalicylic acid reagent (Miller, 1959). Amino acid composition was determined by Agrobio (Rennes, France) according to the European Commission (2009).

\section{Preparation of Protein Stock Solutions and Suspension from Raw Materials}

Fava Bean Proteins. The fava bean protein concentrate was suspended in a $50 \mathrm{~m} M$ phosphate buffer at $\mathrm{pH} 7$ using a solid-to-buffer ratio of 1:8 (wt/ vol) under vigorous stirring for approximately $2 \mathrm{~h}$ at $25^{\circ} \mathrm{C}$. Insoluble material was removed by centrifugation $\left(10,000 \times g, 2 \times 30 \mathrm{~min}, 20^{\circ} \mathrm{C}\right)$. The $\mathrm{CP}$ extract was then acidified at $\mathrm{pH} 4.5$ by adding $0.5 \mathrm{M} \mathrm{HCl}$ dropwise under stirring for 30 min until a stable value was reached. Insoluble protein material was recovered by centrifugation $\left(10,000 \times \mathrm{g}, 30 \mathrm{~min}, 25^{\circ} \mathrm{C}\right)$ of the acidified extract. Supernatants containing water-soluble material and nonglobular protein (albumins, enzymes) were discarded. Protein pellets were washed with de- 
ionized water (DW) using a pellet-to-water ratio of 1:4 (wt/vol) and centrifuged again as above. Washed pellets were pooled and resuspended in DW while applying a pellet-to-water ratio of $1: 3(\mathrm{wt} / \mathrm{vol})$. The $\mathrm{pH}$ was adjusted to $7 \pm 0.1$ by adding $1 M \mathrm{NaOH}$ dropwise under vigorous stirring $(\sim 2 \mathrm{~h})$ until stable. The final suspension was centrifuged using the same parameters as above to obtain the fava bean protein stock solution (10.5 $\pm 1.5 \%$ by weight of soluble protein).

Milk Proteins: Casein and Whey Proteins. The MPC 852B powder was suspended in DW using a solidto-water ratio of 1:10 (wt/vol) under gentle stirring for approximately $4 \mathrm{~h}$ at $60^{\circ} \mathrm{C}$ in a thermostatic bath. The suspension was filtrated through a qualitative ester cellulose paper filter (grade 1, porosity $5 \mu \mathrm{m}$; Whatman, Maidstone, UK) deposited on a Büchner funnel under vacuum. The casein micelle suspension solution $(7.3 \pm$ $0.5 \%$ by weight of total protein) was collected from the filtrate.

The Promilk 802 FB powder was suspended in 3 quarters of the final volume of $\mathrm{DW}$, and $\mathrm{pH}$ was adjusted to $7 \pm 0.1$ by adding $1 \mathrm{M} \mathrm{NaOH}$ dropwise under gentle stirring to avoid foaming. The volume of the suspension was made up with DW to reach a final solid-to-water ratio of 1:5 (wt/vol) while stirring for $2 \mathrm{~h}$ at room temperature. The suspension was centrifuged $(10,000 \times g$, $\left.30 \mathrm{~min}, 25^{\circ} \mathrm{C}\right)$. The whey protein stock solution $(3.5$ $\pm 0.3 \%$ by weight of total protein) was obtained from pooled supernatants. All protein stock solutions and suspensions were stored for less than $48 \mathrm{~h}$ at $4^{\circ} \mathrm{C}$ to minimize bacterial growth because no $\mathrm{NaN}_{3}$ was added.

\section{Protein Mixture Preparation and Acid Gelation}

Each fava bean-dairy protein mixture was prepared by accurately weighting the fava bean, casein, and whey protein stock solutions and suspensions. Mixtures contained $53 \pm 1 \%$ of fava bean proteins and $47 \pm 0.5 \%$ of milk proteins. For the formula with added whey proteins, the weight ratio of casein to whey was 1:0.4, with a slightly higher level of whey proteins than that of raw cow milk; supplementing milk with whey proteins is usually performed during yogurt manufacture to improve texture properties (Cayot and Lorient, 1998). Lactose powder was added to the mixtures to reach $5 \%$ by weight final content, and the weight of each mixture was adjusted with DW to $200 \mathrm{~g}$ in a hermetically sealed 250-mL vessel (Duran Schott, Mainz, Germany). Stirring was carried out at $25^{\circ} \mathrm{C}$ for approximately 15 min. Mixtures were then heated from $25^{\circ} \mathrm{C}$ to $85^{\circ} \mathrm{C}$ in a temperature-controlled bath at a ramp rate of $1^{\circ} \mathrm{C} /$ min, incubated at $85^{\circ} \mathrm{C}$ for $30 \mathrm{~min}$, and then cooled in ice for $15 \mathrm{~min}$.
Each cooled mixture was transferred to plastic vessels with a screw lid. Two kinds of fava bean-dairy mixed gels were provided. The acid-induced gelation of the mixtures was performed at $42^{\circ} \mathrm{C}$ in the presence of either GDL ( $0.5 \mathrm{~g}$ of GDL/g of total protein for the GDL-induced acid mixed gel; A) or a commercial cocktail of lactic bacteria for fermented mixed gels $[25 \mathrm{mg}$ of lactic ferments/g of total protein; produced without $(\mathbf{F})$ or with $(\mathbf{F W})$ whey proteins]. A protein mixture of fava bean, casein, and whey proteins (AW) was also prepared and acidified with GDL to compare change in protein composition with its fermented counterpart FW. However, AW was not used for the in vivo studies to minimize the number of animal experiments and sample analyses. Preliminary experiments showed that the applied GDL amount ( $40 \mathrm{~g}$ of GDL/L of protein mixture) allowed mixture gelation within less than 5 $\mathrm{h}$ at $42^{\circ} \mathrm{C}$ because samples did not collapse when test tubes were inverted. For fermentation, $0.2 \mathrm{~g}$ of lactic acid bacteria powder per liter was added to mixtures $\mathrm{F}$ and $\mathrm{FW}$ following the manufacturer's instructions.

All mixtures were incubated at $42^{\circ} \mathrm{C}$ for $18 \mathrm{~h}$. In parallel, the $\mathrm{pH}$ decrease with time was measured by continuous pH monitoring using a model C561 pH meter (Consort, Turnhout, Belgium). All samples had a $\mathrm{pH}$ value at equilibrium of $4.1 \pm 0.2$. Thereafter, gelled mixtures were unmolded and mashed with a spatula as 1-cm-thick layers in trays, then stored at $-20^{\circ} \mathrm{C}$ and freeze-dried. Dried cakes were crushed and packaged in hermetically sealed plastic bags.

\section{SDS-PAGE}

Sodium dodecyl sulfate PAGE was carried out for each fava bean, casein, and whey protein stock solution and suspension and for the final freeze-dried mixed gels A, AW, F , and FW. Nonreducing (NR) or reducing $(\mathbf{R})$ SDS-PAGE was performed on a discontinuous buffered system using a tris- $\mathrm{HCl}$ polyacrylamide:bis-acrylamide $(\mathrm{C}=2.7 \%$ by weight $)$ stacking gel $(\mathrm{T}=4 \%, \mathrm{wt} / \mathrm{vol}$, $\mathrm{pH}$ 6.8) and running gel $(\mathrm{T}=12 \%$, wt/vol, $\mathrm{pH} 8.9)$ and in the presence of SDS $(0.1 \%$, wt/vol; where T $=$ total content of cross-linking monomers (acrylamide + bisacrylamide) within the electrophoresis gel and $\mathrm{C}=$ bisacrylamide to total monomers (acrylamide + bisacrylamide) weight ratio; Laemmli, 1970). The electrophoresis gel dimensions were $14 \times 16 \mathrm{~cm}$.

The protein stock solutions and suspensions were diluted to $2.5 \mathrm{~g}$ of protein/L with the sample buffer containing $62.5 \mathrm{~m} M$ tris-HCl, $\mathrm{pH} 6.8,10 \%$ glycerol (wt/ vol), $0.005 \%$ bromophenol blue (wt/vol), and $0.2 \%$ SDS (wt/vol) without (NR) or with (R) $1 \%$ (wt/vol) dithiothreitol. The casein micelle suspension was diluted to 
$5 \mathrm{~g}$ of protein/L in a denaturing buffer (weight ratio 1:40) containing $2 \%$ SDS (wt/vol), $6 M$ urea, $100 \mathrm{mM}$ tris- $\mathrm{HCl}, \mathrm{pH} 8.5$, and $10 \mathrm{~m} M$ EDTA and then mixed (volume ratio 1:1) with the sample buffer as above.

For protein analysis of the different freeze-dried mixed gels, each dry sample was resuspended in the same denaturing buffer (weight ratio of 1:50) used for casein proteins and stirred under moderate heating $\left(60^{\circ} \mathrm{C}\right)$ until complete solubilization. Protein samples were then mixed at volume ratio 1:1 with the sample buffer. Under R conditions, samples were heated for 10 min in boiling water. Each well was loaded with $10 \mu \mathrm{L}$ of sample ( $5 \mathrm{mg}$ of protein $/ \mathrm{mL}$ ). Wide-range molecular weight (Mw) standards (S8445, Precision Plus Protein TM standards, Sigma) were deposited in a separate lane. Protein bands precipitated in the presence of TCA $(12 \%$, wt/vol) were stained with Coomassie Blue R-250 $(0.125 \%$, wt $/ \mathrm{vol})$ in $20 \%$ (vol/vol) ethanol, whereas destaining was performed using $5 \%$ (vol/vol) acetic acid and 20\% (vol/vol) ethanol until the background was colorless. The destained gels were scanned with a ChemiDoc XRS+ System (Bio-Rad, Hercules, CA), and densitometric analysis using ImageLab (version 3) software was performed as described elsewhere (Mession et al., 2017a). As determined from the densitogram of total migrating polypeptides with $\mathrm{Mw}$ lower than 200 $\mathrm{kDa}$ in one lane, the relative content of a polypeptide of interest $(P)$ was correlated with its band intensity $\left(I_{P}\right.$; i.e., the integrated area beneath its peak ratioed to total area; Equation 1):

$$
\% P=\frac{I_{P}}{\sum_{i} I_{i}} .
$$

Total lane intensity ratio NR/R $\left(\leq 1 ; R_{t o t}\right)$ was applied to estimate the relative content of migrating polypeptides under NR conditions in the running gel, considering that all polypeptides in the sample under $\mathrm{R}$ conditions could migrate in the running gel (Equation 2):

$$
R_{t o t}=\frac{\sum_{i} I_{i \mathrm{NR}}}{\sum_{i} I_{i \mathrm{R}}} .
$$

To evidence possible proteolysis of a particular polypeptide during gelation of the mixtures by lactic bacteria, patterns under $\mathrm{R}$ conditions of the acidified samples $\mathrm{A}$ and AW in the presence of GDL were compared with their fermented counterparts $\mathrm{F}$ and $\mathrm{FW}$, respectively. Note that the AW gel formula was analyzed in particular to compare its polypeptide composition against that of FW. According to total nitrogen determination, the same total protein amount from the freeze-dried mixed gels could be deposited in each well. Hence, change in electrophoretic patterns of the paired samples A-F and AW-FW could be attributable to proteolysis at lactic acid fermentation of the F and FW samples. Proteolysis level $(\leq 1)$ of the polypeptide $P$ (of band intensity $I$ ) was calculated according to Equation 3:

$$
\text { proteolysis level }(P)=1-\frac{I_{P_{\mathrm{F} ; \mathrm{FW}}}}{I_{P_{\mathrm{A} ; \mathrm{AW}}}} \text {. }
$$

A proteolysis level of 0 indicates no apparent proteolysis. To ensure reliable results, the densitometric analysis of each sample was conducted on 3 repetitions of the gel electrophoresis, whereas each sample was deposited under NR and R conditions on the same gel. Given the potential bias from staining and destaining and optical settings (contrast, brightness) from one SDS-PAGE experiment to another, it was estimated via preliminary tests that the standard deviation of the average polypeptide band intensity, calculated from 3 repeated lanes of the protein sample deposited on the same gel electrophoresis, of $\pm 20 \%$ was within the experimental error. Thus, a proteolysis level in the range of 0 to 0.2 was not considered significant to evidence proteolysis.

\section{In Vivo Study}

Animals and Experimental Protocols. All facilities and procedures were approved by the institution's animal ethics committee (Comité d'Ethique en Matière d'Expérimentation Animale Auvergne; permission no. C2EA-02) and were used in accordance with the European guidelines for the care and use of laboratory animals (2010-63UE). Thirty young (1 mo old) male Wistar rats purchased from Janvier (Le Genest-St-Isle, France) were housed individually in the animal facility of the research unit (agreement no. C6334514) with free access to water and were kept under controlled conditions $\left(12 \mathrm{~h}-12 \mathrm{~h}\right.$ light-dark cycle; temperature: $20^{\circ} \mathrm{C}-$ $22^{\circ} \mathrm{C}$ ). All experiments were conducted to avoid animal discomfort and to minimize animal pain and distress.

After a week of acclimatization, the rats were randomized into 3 groups ( $\mathrm{n}=10 /$ group): (1) a group fed a diet containing fava bean and casein proteins from GDL-induced acid gel A, (2) a group fed a diet containing fava bean and casein proteins from the fermented gel F, and (3) a group fed a diet containing a protein mixture of fava bean, casein, and whey proteins from the fermented gel FW. All the diets manufactured from the freeze-dried mixed gels were isoproteic and isocaloric and were provided to rats for $21 \mathrm{~d}$. The powdered diets were packaged in plastic bags and stored at $4^{\circ} \mathrm{C}$. 
Weight and food consumption were measured weekly. At the end of the 21-d period, fasted (overnight) rats were killed under anesthesia. Skeletal muscles and liver were quickly removed, weighed, frozen in liquid nitrogen, and stored at $-80^{\circ} \mathrm{C}$ until analysis.

Body Composition. Body composition (fat and lean masses) was measured at the beginning and end of the in vivo study (after $21 \mathrm{~d}$ ) using an EchoMRI device (Echo Medical Systems, Houston, TX). The principle of EchoMRI is based on nuclear magnetic resonance imaging that uses the magnetic properties of atoms to determine body composition of the nonanesthetized living rat. For this measure, rats were fasted overnight with unlimited access to drinking water.

Nitrogen Digestibility. In the last week, rats were placed in metabolic cages for $4 \mathrm{~d}$. Urine and feces were collected to determine total nitrogen content using Dumas' method (Dumas, 1962) at Institut UniLaSalle (Beauvais, France). To evaluate the quality of dietary proteins, apparent and true nitrogen $(\mathrm{N})$ digestibility and net protein utilization were calculated using Equations 4, 5, and 6 (Proll et al., 1998):

$$
\text { apparent digestibility }(\%)=\frac{\text { ingested } \mathrm{N}-\text { fecal N }}{\text { ingested } \mathrm{N}} \times 100 \text {, }
$$

$$
\begin{aligned}
& \text { true digestibility }(\%)= \\
& \frac{\text { ingested } \mathrm{N}-(\text { fecal } \mathrm{N}-\text { fecal endogenous } \mathrm{N})}{\text { ingested } \mathrm{N}} \times 100,
\end{aligned}
$$

$$
\begin{aligned}
& \text { net protein utilization }(\%)= \\
& \frac{\text { ingested } \mathrm{N}-\left(\begin{array}{l}
\text { fecal } \mathrm{N}+\text { urinary } \mathrm{N}-\text { fecal endogenous } \mathrm{N} \\
- \text { urinary endogenous } \mathrm{N}
\end{array}\right)}{\text { ingested } \mathrm{N}} \times 100 .
\end{aligned}
$$

Endogenous nitrogen losses originate from various sources, including saliva, bile, pancreatic secretions, sloughed-off epithelial cells, mucin, and serum albumin (Nyachoti et al., 1997). Fecal and urinary endogenous nitrogen were deduced from a young rat group $(\mathrm{n}=10)$ that received a nitrogen-free diet during the metabolic cage period.

Tissue Protein Extraction and Content. Total proteins were extracted from $50 \mathrm{mg}$ of soleus, plantaris, and tibialis muscles and liver in $500 \mu \mathrm{L}$ of SET extraction buffer (sucrose $0.25 M+$ EDTA $2 \mathrm{~m} M+$ Tris $10 \mathrm{mM}, \mathrm{pH} 7.4)$. After stirring $(10 \times 10 \mathrm{~s})$ with a Mini-Beadbeater device (BioSpec Products, Barlesville, OK), the supernatant was transferred into a hemolysis tube and sonicated for $3 \times 30 \mathrm{~s}$ at $70 \%$ of maximum power (Vibracell 75185, VWR International, Radnor, PA). After protein extraction, a colorimetric protein assay was performed. The standard range was made from BSA stock solution at $0.2 \mathrm{mg} / \mathrm{mL}$ deposited concurrently with the samples on a 96 -well microplate. A bicinchoninic acid (BCA) working reagent consisting of reagents $\mathrm{A}, \mathrm{B}$, and $\mathrm{C}$ (at a volume ratio of 25:24:1) of the Micro BCA protein assay kit (Thermo Fisher Scientific, Waltham, MA) was also added. Each plate was covered with an adhesive film (VWR International) to prevent sample evaporation. Sample protein determination was estimated as BSA equivalent and measured at a wavelength of $562 \mathrm{~nm}$ using a microplate reader (microplate spectrophotometer, Epoch Biotek, Winooski, $\mathrm{VT}$ ) after incubation for $1 \mathrm{~h}$ at $37^{\circ} \mathrm{C}$ without stirring. Results were given as percentage of DM for protein concentration. Total protein content in muscle and liver was expressed in milligrams of protein.

\section{Statistical Analyses}

Results were expressed as mean \pm standard deviation and tested for significance by 1-way ANOVA using a post hoc test (protected least significant difference) set at $P<0.05$. All statistical analyses were performed using Statview (version 5) software (SAS Institute Inc., Cary, NC).

\section{RESULTS}

\section{Electrophoretic Patterns of Single-Protein Samples (Unheated)}

Single-Casein Micelle Suspension Stock Solution. Casein monomers appeared as thick bands of $\mathrm{Mw}$ in the range of approximately 24 to $35 \mathrm{kDa}$ (Figure 1a). Under $\mathrm{R}$ conditions, total casein monomers $\left(\alpha_{\mathrm{S}^{-}}\right.$, $\alpha_{\mathrm{S}^{-}}, \beta-, \kappa^{-}$, and $\gamma$-casein as considered as partially hydrolyzed $\beta$-casein) accounted for around $84.5 \pm 13.7 \%$ of total proteins (Figure 1a, lane 2; Table 1). As casein monomers are glycoproteins, their migration did not depend only on their Mw, so bands were assigned according to previous data (Beliciu and Moraru, 2013). Owing to SDS-PAGE under R conditions and densitometric analysis conducted on the casein micelle stock suspension, protein composition is typical of a commercial milk protein concentrate (MPC) enriched in casein micelles. According to the supplier, such raw material is usually used to enhance curd texture during cheese manufacture, displaying a low level of heat-denatured whey proteins. Indeed, it was observed that residual $\beta-\mathrm{LG}$ and low-Mw protein material, including $\alpha-\mathrm{LA}$, 

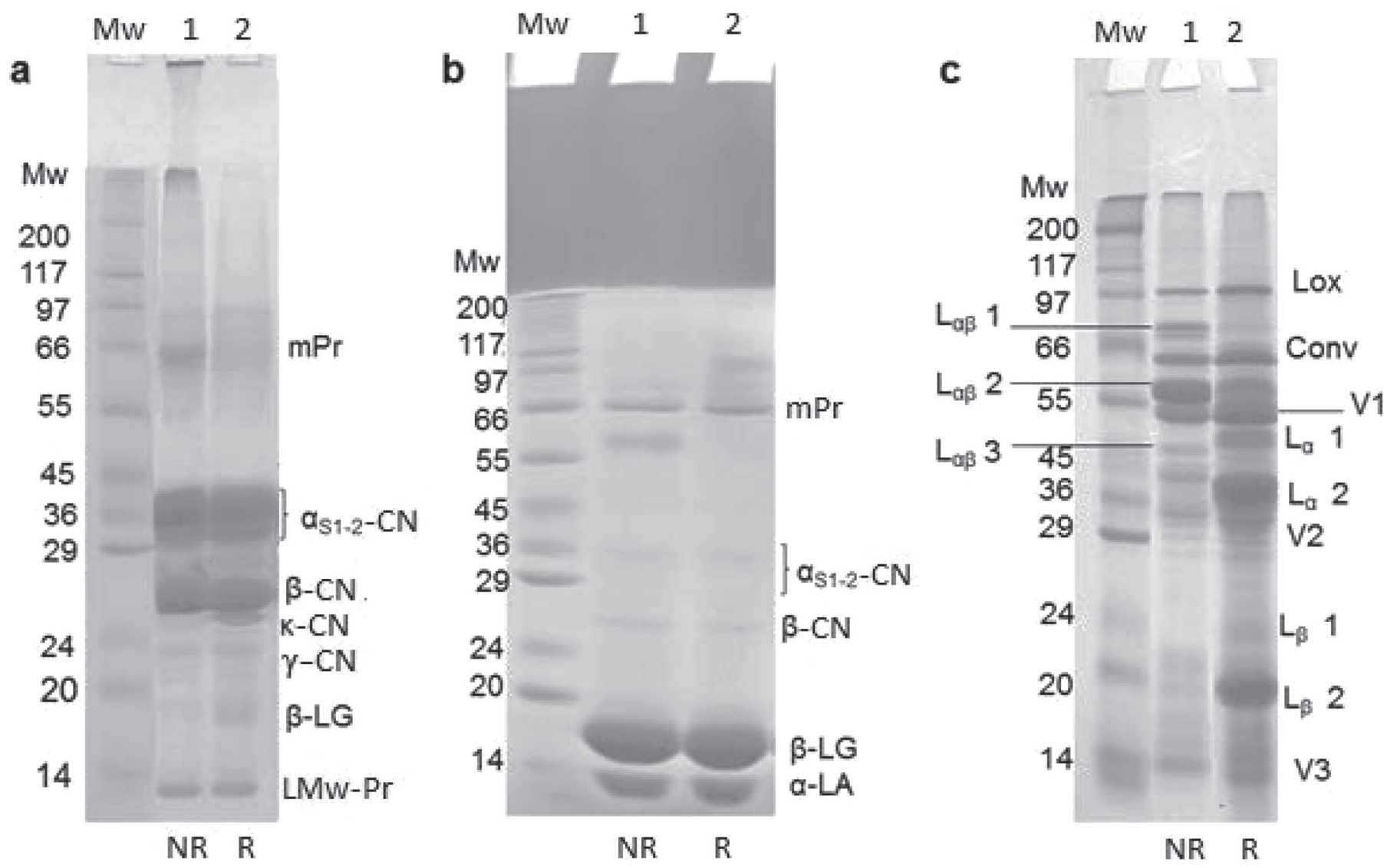

Figure 1. Electrophoretic patterns $[\mathrm{T}=12 \%$, where $\mathrm{T}=$ total content of cross-linking monomers (acrylamide + bisacrylamide) within the electrophoresis gel] of single-protein samples: (a) casein micelle suspension, (b) whey protein, and (c) fava bean protein stock solutions. Mw $=$ molecular weight markers; $\mathrm{NR}=$ nonreducing condition; $\mathrm{R}=$ reducing condition; $\mathrm{mPr}=$ minor whey proteins and $\alpha_{\mathrm{S} 2^{-}} \mathrm{CN}$ dimers; $\alpha_{\mathrm{S} 1-2^{-}}, \beta-, \kappa^{-}$, and $\gamma-\mathrm{CN}=$ casein monomers; LMw-Pr $=$ low-Mw proteins (proteose peptone, $\alpha-\mathrm{LA}$ ); $\mathrm{L}_{\alpha \beta}=$ main legumin subunits: $\mathrm{L}_{\alpha}$ and $\mathrm{L}_{\beta}=$ acidic and basic 1-2 polypeptides constitutive of the legumin subunits, respectively; Lox = lipoxygenases; Conv = convicilin; $\mathrm{V}_{1-3}=$ vicilin polypeptides.

accounted for 1.5 and $8.8 \%$ (Table $1, \mathrm{R}$ conditions) of total polypeptides, respectively. Compared with conventional cow milk (Cayot and Lorient, 1998), the $\alpha-\mathrm{LA}$ and $\beta-\mathrm{LG}$ summed content of the casein-enriched MPC product used in this work was 5 -fold lower. Based on relative contents, the total caseins $/(\alpha-\mathrm{LA}+\beta-\mathrm{LG})$ polypeptide ratio is within the reported range of 5 to 9 for natural cow milk (Cayot and Lorient, 1998) and $33.6 \pm 1.4$ for the casein-enriched MPC product according to densitometric analysis (Table 1). During manufacture of MPC, a great majority of $\alpha$-LA (hardly detectable at the bottom of the electrophoretic profile) and $\beta-L G$ were thus eliminated. Comparing the casein stock suspension under NR and $\mathrm{R}$ conditions (Figure 1a), the increasing band intensity of $\beta-L G$ would indicate that this was mainly coaggregated via disulfide bonds to k-casein (Cayot and Lorient, 1998). Such covalent aggregation, even if limited, resulted from heat sanitization of the milk performed upon manufacture of the MPC product. Additionally, minor whey protein bands ( $\mathrm{Mw}$ of $\sim 60-90 \mathrm{kDa}$ ) may consist of lactoferrin, $\mathrm{IgE}$, and BSA as well as disulfide-bonded proteins such $\alpha_{\mathrm{S} 2}$-casein dimers $(\sim 62 \mathrm{kDa}$; Figure 1a, lane 1$)$. Under $\mathrm{R}$ conditions, the breakup of disulfide bonds released the monomers, and the minor whey protein band disappeared (Figure 1a, lane 2). Likewise, the $\kappa$-casein $(\sim 24-25 \mathrm{kDa})$ band was evidenced below the main $\beta$-casein band, whereas it was barely detectable under NR conditions. Micellar $\kappa$-casein was mainly associated as disulfide-bonded multimers of high $\mathrm{Mw}(>500 \mathrm{kDa})$ and thus could not enter the running gel under NR conditions.

Single-Whey Protein Stock Solution. According to electrophoretic patterns, the $\beta$-LG band predominated ( $\sim 57 \%$ of total intensity), whereas the main whey proteins $(\alpha-\mathrm{LA}+\beta$-LG) accounted for $82 \%$ of total polypeptides (Figure 1b, lanes 1 and 2; Table 1). Residual and soluble caseins were also detected $(<5 \%)$. 
Table 1. Polypeptide composition of casein and whey protein stock suspension and solution according to SDSPAGE and densitometric analysis

\begin{tabular}{|c|c|c|c|c|c|}
\hline \multirow[b]{3}{*}{ Polypeptide $^{1}$} & \multirow[b]{3}{*}{$\mathrm{Mw}(\mathrm{kDa})$} & \multicolumn{4}{|c|}{ Relative content $^{2}(\%)$} \\
\hline & & \multicolumn{2}{|c|}{ Casein } & \multicolumn{2}{|c|}{ Whey } \\
\hline & & NR & $\mathrm{R}$ & NR & $\mathrm{R}$ \\
\hline $\mathrm{mPr}$ & $90-60$ & $14.0 \pm 0.6$ & $5.2 \pm 1.2$ & 13.7 & $15.1 \pm 0.1$ \\
\hline$\alpha_{\mathrm{S} 1-2}-\mathrm{CN}$ & $35-32$ & $40.1 \pm 5.0$ & $33.8 \pm 5.7$ & 2.2 & $1.8 \pm 0.0$ \\
\hline$\beta-\mathrm{CN}$ & $28-26$ & $27.8 \pm 2.4$ & $23.2 \pm 4.7$ & 1.4 & $1.0 \pm 0.1$ \\
\hline$\kappa-\mathrm{CN}$ & $25-24$ & $5.1 \pm 0.1$ & $17.6 \pm 1.5$ & - & \\
\hline$\gamma-\mathrm{CN}$ & $22-20$ & $4.6 \pm 0.2$ & $10.5 \pm 1.8$ & - & \\
\hline$\beta-L G$ & 17 & $0.5 \pm 0.2$ & $1.5 \pm 0.2$ & 57.3 & $56.1 \pm 4.0$ \\
\hline Low-Mw proteins & $14 ;<10$ & $7.8 \pm 1.0$ & $8.8 \pm 1.2$ & 25.4 & $26 \pm 3$ \\
\hline
\end{tabular}

${ }^{1} \mathrm{mPr}=$ minor whey proteins and $\alpha_{\mathrm{S}^{-}} \mathrm{CN}$ dimers; $\alpha_{\mathrm{S} 1-2^{-}}, \beta-, \kappa^{-}$, and $\gamma-\mathrm{CN}=$ casein monomers; $\mathrm{Mw}=$ molecular weight. Low-Mw proteins include proteose peptone and $\alpha-\mathrm{LA}$. Low-Mw proteins are proteins of molecular weight below $14 \mathrm{kDa}$, as indicated; these included proteose peptone $(<10 \mathrm{kDa})$ and $\alpha$-LA $(14 \mathrm{kDa})$. The Mw column specifies the $\mathrm{Mw}$ range wherein polypeptide bands migrated according to their electrophoretic mobility.

${ }^{2}$ Mean $\pm \mathrm{SD}$ calculated from densitograms of 3 repeated samples on separated lanes. $\mathrm{NR}=$ nonreducing; $\mathrm{R}$ = reducing.

There was no significant difference between patterns under NR and $\mathrm{R}$ conditions, indicating the low denatured state (or noncovalently aggregated) of $\alpha-\mathrm{LA}$ and $\beta$-LG in the starting Promilk commercial powder.

Single Fava Bean Protein Stock Solution. From the SDS-PAGE profile of the fava bean protein stock solution, polypeptides ranged from about 100 to about 14 kDa (Figure 1c, Table 2). Similar to other Leguminosae species, fava bean proteins mainly consist of $7 \mathrm{~S}$ and 11S globulins (Gueguen, 1983). The polypeptide band of apparent $\mathrm{Mw}$ of approximately $100 \mathrm{kDa}$ was identified as lipoxygenase, a lipase usually coextracted with plant globulins (Eskin and Henderson, 1974). Under NR conditions, most polypeptide bands were attributable to legumin subunits $\left(\mathrm{L}_{\alpha \beta 1}, \mathrm{~L}_{\alpha \beta 2}\right.$, and $\left.\mathrm{L}_{\alpha \beta 3}\right)$, accounting for approximately $35 \%$ of total band intensity $(\sim 72$, $55-57$, and $44 \mathrm{kDa}$; Table 2), whereas $\mathrm{L}_{\alpha 32}$ represented $65 \%$ of total (summed) legumin bands intensity (Figure 1c, lane 1). Fava legumin subunits are reported to be peculiarly heterogeneous (Wright and Boulter, 1974). Under $\mathrm{R}$ conditions, the breakup of disulfide bonds led to the dissociation of at least 2 acidic $\left(\mathrm{L}_{\alpha 1}\right.$ and $\mathrm{L}_{\alpha 2} ; \sim 46$ and $36 \mathrm{kDa}$, respectively) and 2 basic $\left(\mathrm{L}_{\beta 1}\right.$ and $\mathrm{L}_{\beta 2} ; \sim 21$ and $18 \mathrm{kDa}$, respectively) legumin polypeptides (Figure 1c, lane 2), whereas a nonlegumin subunit band with an $\mathrm{Mw}$ of approximately $56 \mathrm{kDa}$ was detected at the same position as the disrupted $\mathrm{L}_{\alpha \beta 2}$ subunit. Like $11 \mathrm{~S}$ soy glycinin and pea legumin, 11S fava bean legumins are hexamers with an Mw of approximately 300 to 370 $\mathrm{kDa}$ made up with $\mathrm{L}_{\alpha \beta}$ subunits with an $\mathrm{Mw}$ of on average 50 to $60 \mathrm{kDa}$, each stabilized by intermolecular disulfide bonds, whereas subunits are held together via noncovalent bonds. Several vicilin polypeptides $\left(\mathrm{V}_{1}, \mathrm{~V}_{2}\right.$, and $\mathrm{V}_{3}$; mainly $\sim 48-52,26-28$, and $15 \mathrm{kDa}$ ) and convicilin (11\%, $66 \mathrm{kDa}$; Bailey and Boulter, 1972) were also observed. Their related bands were not found to differ under NR and R conditions, as 7S proteins are devoid of sulfur-containing AA (Derbyshire et al., 1976).

\section{Fava Bean-Dairy Protein Mixture Formulation and Chemical Composition of the Dried Mixed Gels}

The protein composition of fava bean-dairy mixtures before gelation and the chemical composition of the

Table 2. Polypeptide composition of fava bean protein stock solution according to SDS-PAGE and densitometric analysis

\begin{tabular}{lccc}
\hline & & \multicolumn{2}{c}{ Relative content $^{3}(\%)$} \\
\cline { 3 - 4 } Polypeptide $^{1}$ & $\mathrm{Mw}^{2}$ & & $\mathrm{R}$ \\
\hline Lox & $(\mathrm{kDa})$ & $\mathrm{NR}$ & $6.3 \pm 0.4$ \\
Conv & 100 & $4.6 \pm 0.5$ & $8.9 \pm 0.5$ \\
$\mathrm{~L}_{\alpha \beta 1}$ & 66 & $10.9 \pm 0.6$ & \\
$\mathrm{~L}_{\alpha \beta 2}$ & 72 & & \\
$\mathrm{~L}_{\alpha \beta 3}$ & 55 & $33.3 \pm 2.2^{4}$ & \\
$\mathrm{~V}_{1}$ & 44 & & \\
$\mathrm{~L}_{\alpha 1}$ & $52-48$ & $11.7 \pm 0.5$ & $12.4 \pm 0.1$ \\
$\mathrm{~L}_{\alpha 2}$ & 46 & & \\
$\mathrm{~V}_{2}$ & 36 & $7.2 \pm 0.1^{4}$ & $23.4 \pm 0.1^{4}$ \\
$\mathrm{~L}_{\beta 1}$ & $28-26$ & $16.8 \pm 3.5$ & $9.1 \pm 0.1$ \\
$\mathrm{~L}_{\beta 2}$ & 21 & & \\
$\mathrm{~V}_{3}$ & 18 & $1.7 \pm 0.2^{4}$ & $17.8 \pm 0.5^{4}$ \\
\hline & $15 ;<10$ & $14.3 \pm 1.2$ & $14.8 \pm 0.1$ \\
\hline
\end{tabular}

${ }^{1}$ Lox $=$ lipoxygenases; Conv $=$ convicilin; $\mathrm{L}_{\mathrm{\alpha} \beta}=$ main legumin subunits; $\mathrm{L}_{\alpha}$ and $\mathrm{L}_{\beta}=$ acidic and basic 1-2 polypeptides constitutive of the legumin subunits, respectively; $\mathrm{V}_{1-3}=$ vicilin polypeptides.

${ }^{2} \mathrm{Mw}=$ molecular weight range wherein the polypeptide bands migrated according to their electrophoretic mobility.

${ }^{3}$ Mean \pm SD calculated from densitograms of 3 repeated samples on separated lanes. $\mathrm{NR}=$ nonreducing; $\mathrm{R}=$ reducing.

${ }^{4}$ The total legumin subunits content $\left(\mathrm{L}_{\alpha \beta}\right)$ was calculated from summed intensities $\mathrm{L}_{\alpha \beta 1}+\mathrm{L}_{\alpha \beta 2}+\mathrm{L}_{\alpha \beta 3}$, likewise for $\mathrm{L}_{\alpha}\left(\mathrm{L}_{\alpha 1}+\mathrm{L}_{\alpha 2}\right)$ and $\mathrm{L}_{\beta}\left(\mathrm{L}_{\beta 1}\right.$ $+\mathrm{L}_{\beta 2}$ ).

${ }^{5}$ The $\mathrm{L}_{\alpha \beta 1-3}$ bands disappeared under $\mathrm{R}$ conditions. A nonlegumin polypeptide of $\mathrm{Mw} \sim 56 \mathrm{kDa}$ remained. 
Table 3. Formulation of the fava bean-milk protein mixtures and chemical composition of the fava bean-dairy mixed gels subsequently freezedried $^{1}$

\begin{tabular}{|c|c|c|c|c|}
\hline Item & $\mathrm{A}$ & $\mathrm{F}$ & $\mathrm{AW}$ & FW \\
\hline \multicolumn{5}{|c|}{ Stock suspension/solutions (\% protein by weight) } \\
\hline Casein & $3.7 \pm 0.2$ & $3.7 \pm 0.2$ & $2.7 \pm 0.2$ & $2.7 \pm 0.2$ \\
\hline Lactose powder ( $\%$ by weight) & 5 & 5 & 5 & 5 \\
\hline \multicolumn{5}{|c|}{ Freeze-dried gels (wt\% composition) } \\
\hline Protein $^{2}$ & $45.7 \pm 2.1$ & $58.0 \pm 2.4$ & $49.6 \pm 1.1$ & $61.8 \pm 0.5$ \\
\hline $\mathrm{Ash}^{2}$ & $5.4 \pm 0.6$ & $6.2 \pm 0.2$ & $7.1 \pm 1.0$ & $7.0 \pm 1.1$ \\
\hline
\end{tabular}

${ }^{1} \mathrm{~A}=$ glucono- $\delta$-lactone induced acid mixed gel; $\mathrm{AW}=$ glucono- $\delta$-lactone induced acid mixed gel with whey proteins; $\mathrm{F}=$ fermented mixed gel; $\mathrm{FW}=$ fermented mixed gel with whey proteins.

${ }^{2}$ Results are expressed on a DM basis as mean $\pm \mathrm{SD}$.

${ }^{3}$ Calculated as wt $\%$ carbohydrate $=1-\mathrm{wt} \%($ protein + fat + ash $)$.

resulting freeze-dried gels are given in Table 3. All fava bean-dairy protein mixtures contained 2-fold higher proteins than typical dairy yogurt. All dried mixed gels could be denoted as protein concentrates $(\geq 45 \%$ by weight). The gelation process clearly influenced the relative amounts of protein and carbohydrate. Compared with their acidified counterparts, the dried and fermented samples F and FW had lower carbohydrate content (approximately $-12 \%$ by weight), whereas protein content increased comparably. Lactic bacteria metabolism thus led to a decrease of about $28 \%$ of the initial reducing sugar content (lactose) in both $\mathrm{F}$ and FW samples. Regardless of mixed gel formulation, the elevated salt content ( $>5 \%$ by weight) in all dried samples may result from the use of acid and base solutions during the fava bean protein extraction procedure.

\section{Electrophoretic Patterns of the Dried Mixed Gels}

Figure 2 shows the electrophoretic patterns of the different dried mixed gels according to total protein composition and gelation process. A densitometric analysis was conducted to estimate difference in polypeptide composition between samples (Table 4). It should be specified that the amount of each dried sample was adjusted before analysis so that the same total protein load $(50 \mu \mathrm{g} / \mathrm{sample})$ was deposited in each lane to allow semiquantitative comparisons between lanes. Polypeptide bands of dried mixed gels were attributed according to their position $(\mathrm{Mw})$ determined in single-protein samples (Figure 1). Bands of $\mathrm{Mw}$ in the range of approximately 55 to 70 and below $15 \mathrm{kDa}$ were unresolved because fava bean and milk polypeptides of close $\mathrm{Mw}$ could overlap (called $\mathrm{x}_{1}$ and $\mathrm{x}_{2}$, respectively; Table 4 ).

All samples underwent the same heating procedure $\left(85^{\circ} \mathrm{C}, 30 \mathrm{~min}\right)$ before gelation. Lanes of the same preheated sample under $\mathrm{NR}$ and $\mathrm{R}$ conditions before gelation were compared with evidence polypeptides involved in covalent aggregation (i.e., where new interprotein disulfide bridges are established between heat-denatured proteins containing sulfur AA). Change in protein interaction due to heat denaturation was investigated for the fava bean-casein mixed protein gels in the absence $(\mathrm{A}, \mathrm{F})$ or presence $(\mathrm{AW}, \mathrm{FW})$ of whey protein.

Effect of Heat Treatment on Polypeptide Composition. Under NR conditions, high-Mw covalent aggregates $(>200 \mathrm{kDa})$ were evidenced by a thick band of low resolution entrapped in the stacking gel (Figure 2, lanes 1-4). There was an absence of legumin subunit bands $\mathrm{L}_{\alpha \beta 1}$ and $\mathrm{L}_{\alpha \beta 3}$ ( $\sim 72$ and $44 \mathrm{kDa}$, respectively) compared with the unheated fava bean protein stock solution (Figure 1c, lane 3). According to total lane intensity ratio $\mathrm{NR} / \mathrm{R}$ calculations (Equation 2), values lower than 1 were indicative of nonmigrating polypeptides $(>200 \mathrm{kDa})$ due to thermal aggregation that involved disulfide bonds (Table 4). These were disrupted under $\mathrm{R}$ conditions, releasing several migrating polypeptides, such as $\mathrm{L}_{\alpha 2}(\sim 36 \mathrm{kDa}), \mathrm{L}_{\beta 1}(21 \mathrm{kDa})$, and $\mathrm{L}_{\beta 2}(18 \mathrm{kDa}$; Figure 2, lanes $5-8)$. The $\beta$-LG band (17 $\mathrm{kDa}$ ) was also absent under NR but detectable under $\mathrm{R}$ conditions, noticeably for both AW and FW samples. Under $\mathrm{R}$ conditions, densitometric analysis showed that the relative amount of $\beta$-LG monomers was about 2 -fold higher in both AW and FW mixed gels than in A and F (Table 4).

Effect of Gelation Procedure on Polypeptide Composition. The electrophoretic patterns of the GDL-induced acid mixed gels (A and AW) compared with their fermented counterparts (F and FW) showed no differences in the relative amount of each identified polypeptide (Table 4). Hence, based on these 


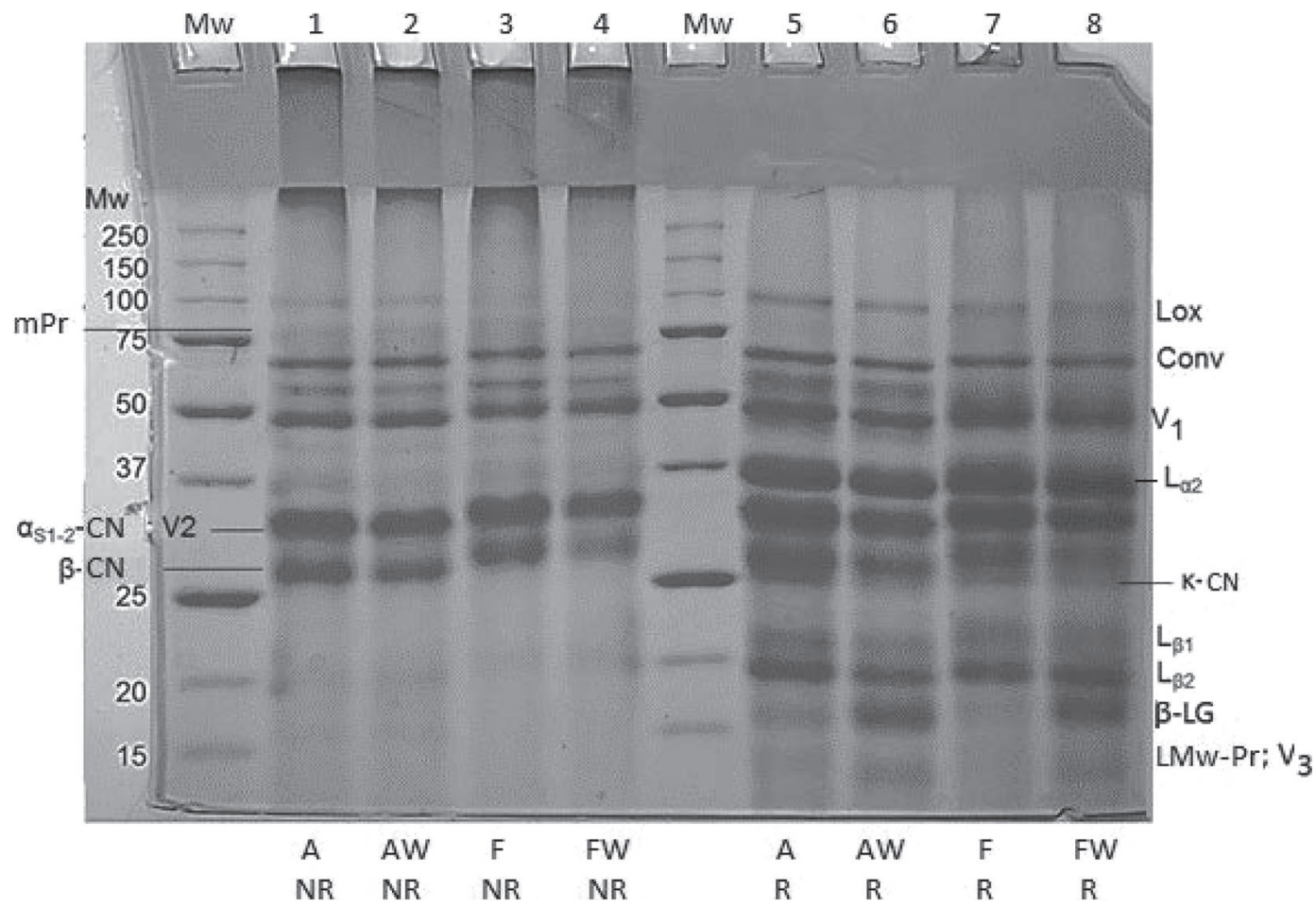

Figure 2. Electrophoretic patterns $[\mathrm{T}=12 \%$, where $\mathrm{T}=$ total content of cross-linking monomers (acrylamide + bisacrylamide) within the electrophoresis gel] of the fava bean-dairy mixed gels. A = glucono- $\delta$-lactone induced acid mixed gel; AW = glucono- $\delta$-lactone induced acid mixed gel with whey proteins; $\mathrm{F}=$ fermented mixed gel; FW = fermented mixed gel with whey proteins; Mw = molecular weight markers; NR $=$ nonreducing condition; $\mathrm{R}=$ reducing condition; $\mathrm{mPr}=$ minor whey proteins and $\alpha_{\mathrm{S}^{-}} \mathrm{CN}$ dimers; $\alpha_{\mathrm{S} 1-2^{-}}, \beta-, \kappa^{-}$, and $\gamma-\mathrm{CN}=$ casein monomers; $\mathrm{LMw}-\mathrm{Pr}=$ low-Mw proteins (proteose peptone, $\alpha-\mathrm{LA}$ ) $; \mathrm{L}_{\alpha \beta}=$ main legumin subunits: $\mathrm{L}_{\alpha}$ and $\mathrm{L}_{\beta}=$ acidic and basic $1-2$ polypeptides constitutive of the legumin subunits, respectively; Lox $=$ lipoxygenases; Conv $=$ convicilin; $\mathrm{V}_{1-3}=$ vicilin polypeptides.

Table 4. Polypeptide composition of the freeze-dried mixed gels ${ }^{1}$ as determined by densitometric analysis (Figure 2)

\begin{tabular}{|c|c|c|c|c|c|c|c|}
\hline Polypeptide $^{2}$ & $\begin{array}{c}\text { Molecular } \\
\text { weight (kDa) }\end{array}$ & $\begin{array}{l}\text { A }(\% \text { of total } \\
\left.\text { protein }^{3}\right)\end{array}$ & $\begin{array}{c}\mathrm{F}(\% \text { of total } \\
\left.\text { protein }^{3}\right)\end{array}$ & $\begin{array}{l}\text { Proteolysis } \\
\text { level (F/A) }\end{array}$ & $\begin{array}{c}\text { AW ( } \% \text { of total } \\
\left.\text { protein }^{3}\right)\end{array}$ & $\begin{array}{c}\mathrm{FW}(\% \text { of total } \\
\left.\text { protein }^{3}\right)\end{array}$ & $\begin{array}{c}\text { Proteolysis } \\
\text { level }(\mathrm{FW} / \mathrm{AW})\end{array}$ \\
\hline $\operatorname{Lox}^{4}$ & 100 & $2.4 \pm 0.1$ & $2.0 \pm 0.4$ & $0.3 \pm 0.1$ & $2.1 \pm 0.3$ & $2.6 \pm 0.4$ & $0.2 \pm 0.1$ \\
\hline Conv $^{4}$ & 66 & $8.2 \pm 0.2$ & $7.7 \pm 0.7$ & $0.0 \pm 0.0$ & $8.3 \pm 1.5$ & $7.8 \pm 0.0$ & $0.2 \pm 0.0$ \\
\hline $\mathrm{V}_{1}^{4}$ & $52-48$ & $15.2 \pm 3.0$ & $14.1 \pm 3.9$ & $0.2 \pm 0.1$ & $13.6 \pm 3.0$ & $13.7 \pm 2.0$ & $0.2 \pm 0.0$ \\
\hline $\mathrm{L}_{\alpha 2} 4$ & 36 & $12.2 \pm 0.6$ & $14.4 \pm 0.4$ & $0.1 \pm 0.1$ & $13.3 \pm 0.7$ & $15.5 \pm 3.2$ & $0.2 \pm 0.1$ \\
\hline Total casein ${ }^{6}$ & $35-24$ & $31.9 \pm 0.9$ & $33.0 \pm 3.5$ & $0.1 \pm 0.1$ & $26.8 \pm 3.3$ & $23.9 \pm 1.6$ & $0.3 \pm 0.1$ \\
\hline $\mathrm{x}_{2}{ }^{7}$ & $\leq 15$ & $6.8 \pm 0.6$ & $5.2 \pm 1.3$ & $0.6 \pm 0.1$ & $6.7 \pm 0.7$ & $5.0 \pm 0.2$ & $0.5 \pm 0.1$ \\
\hline Total & & 104.5 & 105.2 & - & 101.9 & 98.7 & - \\
\hline $\mathrm{R}_{\text {tot }}^{8}$ & & $0.75 \pm 0.1$ & $0.64 \pm 0.1$ & & $0.74 \pm 0.1$ & $0.56 \pm 0.0$ & \\
\hline
\end{tabular}

${ }^{1} \mathrm{~A}=$ glucono- $\delta$-lactone induced acid mixed gel; $\mathrm{AW}=$ glucono- $\delta$-lactone induced acid mixed gel with whey proteins; $\mathrm{F}=$ fermented mixed gel; $\mathrm{FW}=$ fermented mixed gel with whey proteins.

${ }^{2}$ Lox $=$ lipoxygenases; Conv $=$ convicilin; $V_{\mathrm{i} 1-3}=$ vicilin polypeptides $; \mathrm{L}_{\alpha}$ and $\mathrm{L}_{\beta}=$ acidic and basic $1-2$ polypeptides constitutive of the legumin subunits, respectively; total casein $=$ casein monomers and dimers.

${ }^{3}$ From Equation 1, calculated for samples and lanes under reducing conditions only. Results are means \pm SD calculated from densitograms of 3 repeated samples on separated lanes.

${ }^{4}$ Bands identified as fava bean polypeptides (Figure 1c).

${ }^{5} \mathrm{x}_{1}=$ mixture of fava bean and milk polypeptides.

${ }^{6}$ Bands attributed to milk polypeptides (casein and whey proteins; Figure 1a and b).

${ }^{7} \mathrm{x}_{2}=$ mixture of fava bean and milk polypeptides.

${ }^{8}$ Rtot $=$ total lane (summed polypeptide band intensities) intensity ratio NR/R. From Equation 2, applied to total (i.e., sum) band intensities of the lane. Results are means \pm SD calculated from densitograms of 3 repeated samples on separated lanes. 
Table 5. Composition of the rat $\operatorname{diets}^{1}$

\begin{tabular}{|c|c|c|c|}
\hline $\begin{array}{l}\text { Item ( } \% \text { by weight } \\
\text { unless noted) }\end{array}$ & $\mathrm{A}$ & $\mathrm{F}$ & $\mathrm{FW}$ \\
\hline Protein & 13.8 & 13.8 & 13.7 \\
\hline Carbohydrate & 64.3 & 62.6 & 63.6 \\
\hline Lipids & 6.0 & 6.0 & 6.0 \\
\hline Minerals & 5.1 & 5.1 & 5.1 \\
\hline Vitamins $^{2}$ & 1 & 1 & 1 \\
\hline Energy (kcal/100 g) & 366.7 & 360.3 & 363.3 \\
\hline \multicolumn{4}{|l|}{ AA (mg/g of protein) } \\
\hline NEAA & 569.0 & 578.4 & 568.1 \\
\hline $\mathrm{EAA}$ & 430.9 & 421.6 & 431.9 \\
\hline Histidine & 26.3 & 25.5 & 23.5 \\
\hline Isoleucine & 37.7 & 36.0 & 36.9 \\
\hline Leucine & 84.6 & 86.6 & 94.1 \\
\hline Lysine & 69.4 & 67.8 & 69.5 \\
\hline Cysteine & 7.2 & 7.0 & 10.2 \\
\hline Methionine & 20.5 & 19.5 & 20.7 \\
\hline Tyrosine & 42.1 & 40.6 & 37.9 \\
\hline Phenylalanine & 49.5 & 46.4 & 43.8 \\
\hline Threonine & 39.3 & 38.1 & 39.5 \\
\hline Tryptophan & 9.7 & 10.6 & 12.5 \\
\hline Valine & 44.5 & 43.4 & 43.4 \\
\hline $\mathrm{BCAA}^{3}$ & 166.8 & 166.0 & 174.3 \\
\hline Sulfur $\mathrm{AA}^{4}$ & 27.7 & 26.5 & 30.8 \\
\hline Aromatic $\mathrm{AA}^{5}$ & 91.6 & 87.0 & 81.7 \\
\hline
\end{tabular}

$\overline{{ }^{1} \mathrm{~A}}=$ glucono- $\delta$-lactone induced acid mixed gel; $\mathrm{F}=$ fermented mixed gel; $\mathrm{FW}=$ fermented mixed gel with whey proteins.

${ }^{2}$ Vitamins added to diets.

${ }^{3}$ Branched-chain $\mathrm{AA}=$ isoleucine + leucine + valine

${ }^{4}$ Sulfur $\mathrm{AA}=$ cysteine + methionine

${ }^{5}$ Aromatic $\mathrm{AA}=$ tyrosine + phenylalanine.

results, there was no noticeable effect of lactic acid fermentation on protein composition due to proteolysis compared with GDL-induced acidification. The band intensity $\left(I_{P}\right)$ of a particular polypeptide $(P)$ within the electrophoretic pattern of the GDL-induced acid mixed gels (A and AW samples) was checked as higher or equal to its counterpart detectable in the fermented mixed gels ( $\mathrm{F}$ and FW samples, respectively). Given the accuracy of the comparative densitometric analysis conducted between lanes, the calculated proteolysis level (Equation 3) for a great majority of the polypeptide bands remained within the experimental error and consequently did not show any marked band fading (i.e., decrease in intensity) by proteolysis. There was a slight effect on lipoxygenase $(100 \mathrm{kDa})$ and $\mathrm{x}_{2}$ polypeptides (a mixture of fava bean and milk minor polypeptides; $\mathrm{Mw}$ $\leq 15 \mathrm{kDa}$ ), for which the level of proteolysis was above the experimental error limit, though these accounted for less than approximately $10 \%$ of total polypeptides.

\section{AA Composition of Dried Mixed Gels}

The AA composition of the dried mixed gels A, F, and $\mathrm{FW}$ incorporated into in vivo study diets is given in Table 5. The addition of whey protein in the FW formula resulted in an increase in branched-chain AA content. As valine and isoleucine contents in FW formula were in the same range as $\mathrm{F}$ and $\mathrm{A}$ formulas, increased branched AA content was explained by $10 \%$ higher content in leucine compared with $\mathrm{A}$ and $\mathrm{F}$ formulas. Moreover, the $\mathrm{FW}$ formula was also $14 \%$ richer in sulfur AA content due to the presence of $\beta$-LG, as it is rich in sulfur AA and represents $57 \%$ of whey proteins. More precisely, cysteine was 1.4-fold higher in FW formula compared with $\mathrm{F}$ and A formulas. Moreover, tryptophan content was 18 and $28 \%$ higher in FW than in F and A formulas, respectively. However, aromatic acid content (i.e., phenylalanine and tyrosine) was lower in the $\mathrm{FW}$ formula than in the $\mathrm{F}$ and $\mathrm{A}$ formulas ( 82 vs. 87 and $92 \mathrm{mg} / \mathrm{g}$ protein, respectively). The $\mathrm{F}$ and $\mathrm{A}$ formulas contained a higher quantity of histidine $(+10 \%)$ than the FW formula.

\section{pH Profiles During Gelation}

Kinetics of acidification at $42^{\circ} \mathrm{C}$ of the protein mixtures upon gelation were followed (Figure 3). As an example, change in $\mathrm{pH}$ was measured for the $\mathrm{A}$ and $\mathrm{F}$ fava bean-casein protein mixtures that underwent acidification in the presence of GDL and lactic acid bacteria, respectively. Differences in $\mathrm{pH}$ decrease between the 2 gelled samples were noted. In the presence of GDL, the $\mathrm{pH}$ of mixture A decreased rapidly after 2 $\mathrm{h}$ to a value of approximately 4.5 , within the $\mathrm{pH}$ range of minimum solubility for fava bean proteins and the

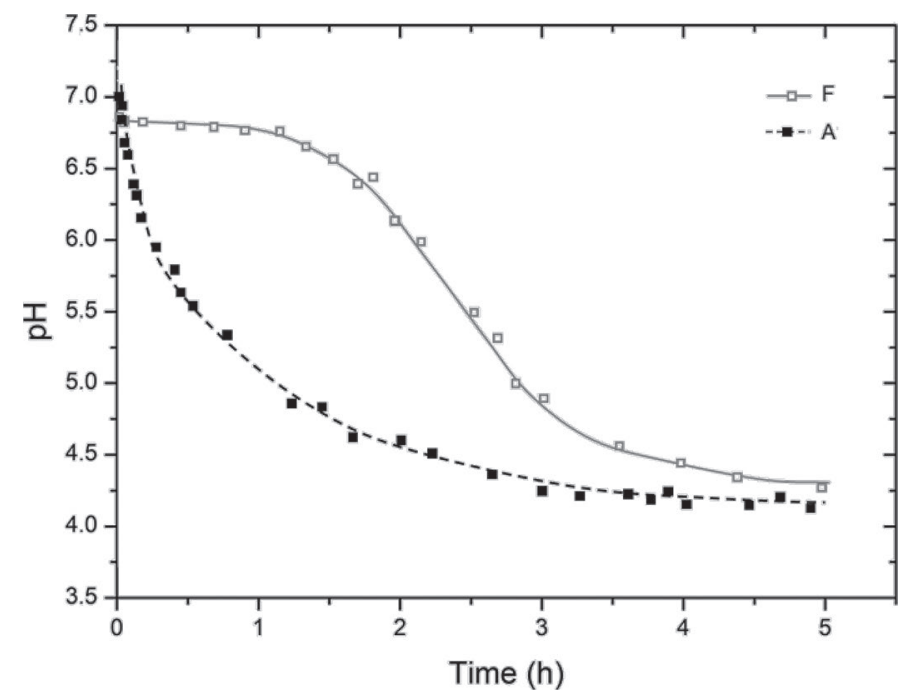

Figure 3. Kinetics of acidification at $42^{\circ} \mathrm{C}$ during gelation of the fava bean-milk protein mixtures. $\mathrm{A}=$ glucono- $\delta$-lactone induced acidification; $\mathrm{F}$ = lactic acid fermentation. 
Table 6. Body weight, food intake, protein efficiency, fat-free mass gain, nitrogen intake, excretion and balance, digestibility, and protein utilization in rats fed fava bean-dairy mixed gels for $21 \mathrm{~d}^{1}$

\begin{tabular}{lccc}
\hline Item & $\mathrm{A}$ & $\mathrm{F}$ & $\mathrm{FW}$ \\
\hline Final BW (g) & $284 \pm 22^{\mathrm{b}}$ & $324 \pm 24^{\mathrm{a}}$ & $339 \pm 31^{\mathrm{a}}$ \\
Food intake (g/d) & $32.6 \pm 5.7^{\mathrm{a}}$ & $28.2 \pm 4.1^{\mathrm{b}}$ & $30.9 \pm 1.4^{\mathrm{ab}}$ \\
Growth rate (g/d) & $5.4 \pm 0.8^{\mathrm{b}}$ & $7.3 \pm 0.7^{\mathrm{a}}$ & $8.1 \pm 1.2^{\mathrm{a}}$ \\
Protein efficiency ratio & $1.2 \pm 0.3^{\mathrm{b}}$ & $1.9 \pm 0.4^{\mathrm{a}}$ & $1.9 \pm 0.2^{\mathrm{a}}$ \\
Fat-free mass (g) & $241 \pm 17^{\mathrm{b}}$ & $266 \pm 17^{\mathrm{a}}$ & $272 \pm 21^{\mathrm{a}}$ \\
Fat-free mass gain (\%) & $66 \pm 10^{\mathrm{b}}$ & $83 \pm 8^{\mathrm{a}}$ & $88 \pm 13^{\mathrm{a}}$ \\
Nitrogen intake $^{2}(\mathrm{~g})$ & $1.67 \pm 0.13$ & $1.67 \pm 0.22$ & $1.75 \pm 0.10$ \\
Fecal nitrogen (g) & $0.27 \pm 0.06^{\mathrm{a}}$ & $0.16 \pm 0.04^{\mathrm{b}}$ & $0.15 \pm 0.02^{\mathrm{b}}$ \\
Urinary nitrogen (g) $_{\text {Nitrogen balance (g) }}$ & $0.81 \pm 0.02^{\mathrm{a}}$ & $0.75 \pm 0.02^{\mathrm{b}}$ & $0.71 \pm 0.02^{\mathrm{c}}$ \\
Apparent digestibility (\%) & $0.59 \pm 0.12^{\mathrm{b}}$ & $0.76 \pm 0.19^{\mathrm{a}}$ & $0.89 \pm 0.10^{\mathrm{a}}$ \\
True digestibility (\%) & $84.0 \pm 3.3^{\mathrm{b}}$ & $90.3 \pm 1.5^{\mathrm{a}}$ & $91.1 \pm 1.5^{\mathrm{a}}$ \\
Net protein utilization (\%) & $89.9 \pm 3.3^{\mathrm{b}}$ & $96.2 \pm 1.9^{\mathrm{a}}$ & $96.7 \pm 1.3^{\mathrm{a}}$ \\
\hline
\end{tabular}

${ }^{{ }^{-c} \mathrm{c}}$ Means within a row with different superscripts are significantly different $(P<0.05)$.

${ }^{1} \mathrm{~A}=$ glucono- $\delta$-lactone induced acid mixed gel; $\mathrm{F}=$ fermented mixed gel; $\mathrm{FW}=$ fermented mixed gel with whey proteins. Results are means \pm SD measured for 10 rats for each group.

${ }^{2}$ Measured in metabolic cages.

reported isoelectric point of casein proteins. In the case of mixture $\mathrm{F}$, at lactic acid fermentation, $\mathrm{pH}$ decreased very slowly from approximately 6.7 to 6.5 after $1 \mathrm{~h} 30$ min then to approximately 4.5 after $4 \mathrm{~h}$ of incubation. At a given incubation temperature, the hydrolysis of GDL that released protons in the medium was readily initiated when powder was dissolved. In contrast, fermentation-induced acidification was slower than GDL-induced acidification, possibly due to metabolic activation that converted lactose into lactic acid and to concomitant bacterial growth.

\section{In Vivo Study}

The effect of different protein formulations (effect of whey protein addition) and gelation processes (GDL- induced acidification or lactic acid fermentation) on growth and protein retention in young rats was evaluated. See Tables 6 and 7 for in vivo data.

Growth Parameters and Body Composition of Rats. Final BW were $14 \%(P=0.002)$ and $19 \%$ higher $(P<0.001)$ in rat groups fed $\mathrm{F}$ and $\mathrm{FW}$ diets, respectively, than the A group (Table 6). Protein efficiency ratio, which represents the contribution of protein diet in rat growth, was about 1.6-fold higher in rats receiving the $\mathrm{F}$ and $\mathrm{FW}$ diets than in those receiving the $\mathrm{A}$ $\operatorname{diet}(P<0.001)$. Growth rate was 35 and $50 \%$ higher for rats fed the $\mathrm{F}$ and $\mathrm{FW}$ diets, respectively, than for those fed the $\mathrm{A} \operatorname{diet}(P<0.001)$. However, food intake content was significantly higher in the A group than in the $\mathrm{F}$ group $(P=0.03)$. Furthermore, fat-free mass gain was $26 \%(P=0.001)$ and $33 \%(P<0.001)$ higher

Table 7. Tissue weight and total protein content in rats fed fava bean-dairy mixed gels for $21 \mathrm{~d}^{1}$

\begin{tabular}{lccc}
\hline Item & A & F & FW \\
\hline Total muscle mass (g) & $0.88 \pm 0.07^{\mathrm{b}}$ & $0.96 \pm 0.07^{\mathrm{a}}$ & $0.99 \pm 0.08^{\mathrm{a}}$ \\
Total protein content (mg) & $140.0 \pm 13.6^{\mathrm{b}}$ & $161.0 \pm 14.8^{\mathrm{a}}$ & $155.1 \pm 12.8^{\mathrm{a}}$ \\
Soleus mass (mg) & $141 \pm 20$ & $144 \pm 9$ & $149 \pm 15$ \\
Protein concentration (\% of DM) & $57.0 \pm 4.9$ & $58.7 \pm 6.1$ & $55.8 \pm 7.8$ \\
Total protein content (mg) & $20.5 \pm 3.6$ & $22.2 \pm 2.1$ & $22.4 \pm 4.5$ \\
Plantaris mass (mg) & $268 \pm 29^{\mathrm{b}}$ & $289 \pm 35^{\mathrm{ab}}$ & $304 \pm 30^{\mathrm{a}}$ \\
Protein concentration (\% of DM) & $69.5 \pm 7.9^{\mathrm{b}}$ & $76.7 \pm 5.1^{\mathrm{a}}$ & $66.0 \pm 5.3^{\mathrm{b}}$ \\
Total protein content (mg) & $46.3 \pm 7.6^{\mathrm{b}}$ & $55.1 \pm 6.3^{\mathrm{a}}$ & $50.4 \pm 6.1^{\mathrm{ab}}$ \\
Tibialis mass (mg) & $474 \pm 34^{\mathrm{b}}$ & $526 \pm 39^{\mathrm{a}}$ & $546 \pm 43^{\mathrm{a}}$ \\
Protein concentration (\% of DM) & $62.1 \pm 6.4$ & $63.2 \pm 4.9$ & $60.0 \pm 7.0$ \\
Total protein content (mg) & $73.2 \pm 7.5^{\mathrm{b}}$ & $83.7 \pm 9.0^{\mathrm{a}}$ & $82.2 \pm 10.3^{\mathrm{a}}$ \\
Liver mass (g) & $9.7 \pm 0.9$ & $10.1 \pm 1.1$ & $10.6 \pm 1.6$ \\
Protein concentration (\% of DM) & $59.5 \pm 8.4$ & $60.1 \pm 4.5$ & $60.4 \pm 5.1$ \\
Total protein content (mg) & $1,884 \pm 207$ & $1,892 \pm 240$ & $2,099 \pm 401$ \\
\hline a,b Means within a row with different superscripts are significantly different $(P<0.05)$. & \\
${ }^{1}$ A = glucono- $\delta$-lactone induced acid mixed gel; F $=$ fermented mixed gel; FW F fermented mixed gel with \\
whey proteins. Results are means \pm SD measured for 10 rats for each group.
\end{tabular}


in rats receiving the $\mathrm{F}$ and $\mathrm{FW}$ diets, respectively, than in those receiving the $\mathrm{A}$ diet.

Evaluation of Protein Quality by Nitrogen Balance in Rats. The nutritional parameters measured served to evaluate the quality of dietary proteins (Table $6)$. Nitrogen intake was unchanged between groups $(P$ $=0.50)$. Fecal nitrogen was about 1.7 -fold higher for the A group than that for both the $\mathrm{F}$ and $\mathrm{FW}$ groups $(P<0.001)$. Urinary nitrogen was $8 \%(P<0.001)$ and $14 \%(P<0.001)$ higher for the A group than for the $\mathrm{F}$ and $\mathrm{FW}$ groups, respectively. As a result, nitrogen balance, which is the difference between nitrogen intake and nitrogen loss by both fecal and urinary routes, was increased for $\mathrm{F}$ and $\mathrm{FW}$ groups compared with the $\mathrm{A}$ group. Apparent digestibility and true digestibility values were about $7 \%$ higher $(P<0.001)$ for the $\mathrm{F}$ and FW groups than for the A group. Finally, the fermented gel FW containing whey protein resulted in improved net protein utilization, which is indicative of increased protein retention. Net protein utilization was $7 \%(P=$ 0.01) higher for the $\mathrm{FW}$ group than for the $\mathrm{F}$ group and $28 \%(P<0.001)$ higher than for the A group.

Tissue Weight and Protein Content. Muscle and liver weights and their protein contents are given in Table 7. Total muscle weight was $13 \%(P=0.002)$ and $9 \%(P=0.04)$ higher for the groups fed the FW and $\mathrm{F}$ diets than the A group, respectively. Total muscle protein content was $11 \%(P=0.02)$ and $15 \%(P=$ 0.003 ) higher for the FW and F groups, respectively, than for the A group. The increase in muscle weight could thus be due to the increase in protein content. Soleus weight $(P=0.56)$ and related protein content $(P=$ $0.48)$ remained unchanged. Plantaris muscle weight was $13 \%$ higher in the FW group than the A group $(P=$ $0.02)$. Tibialis muscle weight was $15 \%(P<0.001)$ and $11 \%(P=0.009)$ higher for the $\mathrm{FW}$ and $\mathrm{F}$ groups than for the A group, respectively. Plantaris muscle protein content was slightly higher $(+9 \%, P=0.19)$ in the FW group and significantly higher $(+19 \%, P=0.009)$ in the $\mathrm{F}$ group than the A group. Tibialis muscle protein content was $12 \%(P=0.04)$ and $14 \%(P=0.02)$ higher in the $\mathrm{FW}$ and $\mathrm{F}$ diet groups, respectively, than in the A group. There were no significant differences between groups in liver weight $(P=0.31)$ and protein content $(P=0.22)$.

\section{DISCUSSION}

Dairy gels were enriched with fava bean proteins from $4 \%$ by weight of total protein in typical dairy yogurt (Favier, 1987) to $8 \%$ by weight for the mixed gels designed here. Fava bean (Vicia faba L.) proteins were selected for this study because this legume is extensively cultivated in different parts of the world (Liene and Sandra, 2016). In addition, fava bean is known to have a low beany flavor when added to some cereal-enriched foods and did not decrease their overall sensory acceptability (Rizzello et al., 2017).

Fava bean-dairy mixed gels were obtained from preheated fava bean-milk protein mixtures and then acidified either with added GDL (A) or by lactic acid fermentation. Indeed, this study aimed to evaluate the effect of gel processes (GDL-induced acidification or lactic acid fermentation) and formulation (effect of whey protein addition) on protein aggregation in these mixed gels and its repercussions on in vivo nutritional parameters in young rats.

The preheating step $\left(85^{\circ} \mathrm{C}, 30 \mathrm{~min}\right)$ of fava beanmilk protein mixtures performed before gelation formed high-Mw protein aggregates involving disulfide linkages and hydrophobic interactions; the latter ones could not be evidenced by SDS-PAGE. Previous investigations on similar heated plant-milk protein mixtures found that denatured plant globulins were more likely to selfaggregate rather than produce coaggregates involving milk proteins (Beliciu and Moraru, 2013; Mession et al., 2017a). Here, protein thermal aggregation mainly involved the fava bean legumin polypeptides $\mathrm{L}_{\alpha 2}$ and $\mathrm{L}_{31-2}$ for all mixtures, as evidenced by SDS-PAGE. According to Zheng et al. (1991, 1992), the fava bean legumin subunits thermally denatured and unfolded their globular structure, thus increasing the exposure of previously buried reactive groups. This resulted in protein interactions via concomitant hydrophobic interactions and disulfide bonding; the soluble large protein aggregates exhibited cold-set gelation properties upon further acidification. As shown by SDS-PAGE, the $\beta$-LG brought by whey protein stock solution in the FW mixture unfolded upon heating and covalently aggregated by sulfhydryl-disulfide bond exchanges involving $\kappa$-casein (Cayot and Lorient, 1998; Donato and Guyomarc'h, 2009). However, the present results did not evidence any interactions between the denatured legumin and $\beta$-LG molecules via disulfide bonds.

Concerning effects of gelation processes (i.e., GDLinduced acidification and lactic acid fermentation), we found no difference between the electrophoretic patterns of $\mathrm{A}-\mathrm{F}$ and $\mathrm{AW}-\mathrm{FW}$ mixed gels and thus no significant proteolysis in the fermented mixed gels. These results are in agreement with a previous study that focused on soymilk gelled products using comparable gelation routes (Grygorczyk, 2012). However, this differed from data reported by Li et al. (2013), who found differences in patterns of soy cheese spread samples produced by GDL-induced acidification versus lactic acid fermentation, where 2 distinct bands at approximately 100 
$\mathrm{kDa}$ were present in patterns of the GDL-induced acid products but absent in the patterns of fermented products. Note that peptides or polypeptide fragments of $\mathrm{Mw}$ lower than $10 \mathrm{kDa}$, which could not be detected with the present SDS-PAGE protocol, may nevertheless have formed.

Interestingly, there was an effect of gelation process on the kinetics of acidification. Acidification in the presence of GDL started rapidly, whereas $\mathrm{pH}$ started to decrease markedly with lactic acid bacteria from 90 min of incubation at $42^{\circ} \mathrm{C}$. This may be due to the effect of rapid hydrolysis of GDL to gluconic acid at $42^{\circ} \mathrm{C}$ responsible for gel acidification (Lucey et al., 1998). This finding is consistent with the results of previous studies (Amice-Quemeneur et al., 1995; Lucey et al., 1998; Azim et al., 2010). In the case of single milk, Lucey et al. (1998) reported that the different acidification rate in the presence of either GDL or lactic acid bacteria could influence the aggregation rate and rearrangement time of protein molecules involved in the gelled network. Using confocal scanning laser microscopy, they demonstrated that fermented dairy gel at $42^{\circ} \mathrm{C}$ (the temperature used in our study) appeared to have a more clustered type of network than the GDLinduced acid gel. Another study found no difference in final microstructure of soymilk gels produced by fermentation compared with GDL-induced acidification despite a difference in acidification rate during gelation at $40^{\circ} \mathrm{C}$ (Grygorczyk, 2012).

Gelation process had an effect on nutrition parameters measured in young rats fed the different formulas of dried mixed gels, as the use of lactic bacteria for gelation of fava bean-casein protein mixtures with $(\mathrm{FW})$ or without $(\mathrm{F})$ whey protein enhanced true protein digestibility $(+7 \%)$ and retention $(+19 \%$ and $+28 \%$ for the $\mathrm{F}$ and $\mathrm{FW}$ diets, respectively), protein efficiency ratio $(+58 \%)$, and growth rate $(+35 \%$ and $+50 \%$ for the $\mathrm{F}$ and $\mathrm{FW}$ diets, respectively) compared with the A diet.

These differences could not be attributed to the protein stock solutions or suspension preparation because GDL-induced acid gel $\mathrm{A}$ and fermented gel $\mathrm{F}$ were produced using the same formulation (i.e., using the same casein-to-fava bean protein weight ratio of 1:1.3). It is well known from the literature that fermentation enhances the in vitro and in vivo protein digestibility of legume and dairy products (Lee et al., 1988; Torres et al., 2006; Coda et al., 2015; Chandra-Hioe et al., 2016). Coda et al. (2015) and Chandra-Hioe et al. (2016) reported increased in vitro protein digestibility of fermented fava bean flour (Vicia faba) by $2 \%$ and fermented desi (Cicer arietinum) by $9.5 \%$ compared with the raw products. Lee et al. (1988) and Torres et al. (2006) also obtained a significantly higher in vivo protein digestibility in fermented yogurt $(+2 \%)$ and fermented legume-enriched pasta $(+6 \%)$, respectively, than in the nonfermented products. We suggest that a residual proteolytic activity of bacteria could be maintained during the in vivo digestive process that could be partially responsible for the improved digestibility of fermented gels compared with GDL-induced acid gel. Indeed, Mater et al. (2005) reported that Streptococcus thermophilus and Lactobacillus delbrueckii ssp. bulgaricus can survive gastrointestinal transit and exert a probiotic effect. Furthermore, according to Ghosh and Ray (2017), probiotic organisms could improve food digestibility via administration of exogenous enzymes. Moreover, Di Cagno et al. (2002) and Coda et al. (2015) previously reported that formation of free AA increased in fermented wheat dough and fava bean flour compared with chemically acidified wheat dough and unfermented fava bean flour. Fermentation, via proteolytic activity of lactic bacteria, could promote the formation of free AA and low-molecular-weight peptides that could not be detected with the SDS-PAGE analysis used here. Protein digestibility may be affected either by level of aggregation and clustering within the gelled network structure or by change in protein structure due to proteolysis phenomena. Given the previous reports discussed above, the higher observable digestibility of proteins in fermented gel formulas $\mathrm{F}$ and $\mathrm{FW}$ may be more likely attributable to proteolysis giving rise to the release of small peptides and free AA that are readily absorbable by rats fed fermented gels.

The better net protein utilization measured for young rats fed fermented mixed gels $\mathrm{F}$ and $\mathrm{FW}$ is in agreement with Aliya and Geervani (1981), who reported that rats fed fermented legume products Bengal gram dhokla (from Cicer arietinum) showed 12\% higher net protein utilization than rats fed the nonfermented product. Here, lactic acid fermentation of fava beancasein mixed protein gels resulted in better growth rate $(+35 \%)$ and protein efficiency ratio (about 1.6-fold higher) than the chemically acidified mixed gels. Rizzello et al. (2017) showed that pasta products enriched with fermented fava bean flour were characterized by a greater protein efficiency ratio $(+10 \%)$, calculated using the model evidenced by Ihekoronye (1981), compared with the nonfermented pasta. Lee et al. (1988) reported that cultured yogurt produced by fermentation led to a significantly higher growth response $(+15 \%)$ and computed protein efficiency ratio $(+9 \%)$ based on AA profile and in vivo digestibility than that evidenced with its acidified counterpart.

Here we found enhanced protein efficiency and protein retention in young rats fed the fermented fava 
bean-casein mixed protein gels containing or not containing whey protein compared with GDL-induced acid mixed gel, which resulted in an increase in muscle mass $(+9 \%)$ and muscle protein content $(+15 \%)$.

The improved protein digestibility of fermented gels could increase the release of free AA. In addition, lowmolecular-weight peptides and readily available free AA, especially essential AA, may have formed during fermentation (Di Cagno et al., 2002; Kopf-Bolanz et al., 2014; Coda et al., 2015). Though not detected in the electrophoretic patterns of the dried mixed protein gels, the contribution of protein proteolysis at lactic acid fermentation could enhance both the protein efficiency and protein retention of fermented gels. This would consequently contribute to the gain in muscle mass and muscle protein content for young rats fed the fermented mixed gels in the presence or absence of whey proteins compared with GDL-induced acid mixed gel.

Concerning the influence of formulation, the addition of whey protein to fermented mixed gel led to higher protein retention $(+7 \%)$ than fermented gel without whey protein in young rats. Some studies have established the concept of "slow" proteins (e.g., casein) and "fast" proteins (e.g., whey) depending on protein digestion rate and AA absorption in the intestine (Boirie et al., 1997; Dangin et al., 2001, 2002, 2003). The whey proteins, which are highly soluble in acidic conditions, could transit rapidly through the stomach and subsequently become hydrolyzed in the duodenum, inducing rapid and significant AA absorption. In contrast, in the presence of stomach acidity, caseins coagulate and induce a slow and prolonged absorption of AA over a longer period (Boirie et al., 1997). Dangin et al. (2003) showed that protein gain was higher after ingestion of a meal containing only whey proteins compared with caseins. The same effect was reported in a study on enzymatically hydrolyzed dairy proteins (Koopman et al., 2009), where in vivo digestion and absorption rates were increased after ingestion of a protein hydrolysate compared with its nonhydrolyzed counterpart, leading to a better body protein retention rate. Note that fermented gel with whey protein was $10 \%$ richer in leucine than in $\mathrm{A}$ and $\mathrm{F}$ gels without whey protein. Previous studies showed that leucine supplementation is able to stimulate muscle protein synthesis in young (Anthony et al., 1999) and old (Dardevet et al., 2002; Rieu et al., 2003) rats and in elderly men (Wall et al., 2013). Moreover, Gryson et al. (2014) suggested that fast-digested protein, such as whey proteins, could induce a high leucine availability and improve postprandial protein retention in older men. Overall, the high anabolic effect of rapidly digested proteins (e.g., hydrolyzed proteins and whey proteins) likely explains the enhanced protein retention observed in young rats fed the fermented gel that contains whey protein and is furthermore liable to have more hydrolyzed proteins and free AA. Borack et al. (2016) compared the effect of isolated whey protein and soy-dairy protein blends ingested by human subjects and showed that these proteins induced similar responses in hyperaminoacidemia and muscle protein synthesis. This is in agreement with a previous study carried out on young adult humans, where ingestion of a soy-dairy protein blend following exercise prolonged blood aminoacidemia and muscle protein synthesis (Reidy et al., 2013). In this regard, Paul (2009) reported that combining soy, casein, and whey proteins is more efficient than the use of a single protein source because it leads to a better-balanced AA profile.

It would have been interesting to complete the present study with an additional control group fed a plant protein-based gel containing only fava bean proteins. This experimental design would have assessed the nutritional benefit of blending fava bean proteins with animal proteins regarding a possible compensation of the well-known low anabolic effect of plant proteins. Nevertheless, the results from this group would have been expected. According to previous data, impaired growth rate, food efficiency, and muscle mass were observed in growing rats fed raw fava bean (Vicia faba) or raw pea seeds nonsupplemented in free sulfur AA compared with the casein group (Martínez et al., 1987; Alonso et al., 2002). In addition, when heated to reduce antinutritional factor content, pea seeds supplemented with free sulfur AA to target rat requirements induced a higher food efficiency and muscle mass than heattreated but nonsupplemented pea seeds (i.e., results comparable with those obtained with casein; Alonso et al., 2002). These results highlight the importance of compensating the unbalanced legume proteins with sulfur AA. Feeding growing rats diets deficient in sulfur AA alters the growing rate and nitrogen balance of animals (Heger and Frydrych, 1985; Sikalidis and Stipanuk, 2010). Hence, rats fed only fava bean proteins were not used in the present work to avoid observing the well-known consequences of sulfur AA deficiency of legume proteins.

It would also have been interesting to evaluate the effect of protein enrichment by comparing mixed gels of the present work ( $8 \%$ by weight protein) with a typical dairy yogurt ( $4 \%$ by weight protein). Digestibility of typical dairy yogurt is well documented in the literature (Alm, 1982; Lee et al., 1988). Therefore, it is highly possible to compare protein digestibility observed in this study with that of typical dairy yogurt reported in the literature (Alm, 1982; Lee et al., 1988). This comparison led us to conclude that the enrichment 
of protein from 4 to $8 \%$ by weight by the addition of fava bean proteins could improve protein digestibility of fava bean-dairy mixed gels compared with typical dairy yogurt.

\section{CONCLUSIONS}

Feeding dairy gels fortified with fava bean proteins induced a protein gain in young rats. The gain was significantly improved when rapidly digested whey proteins were added to the formula. Blending fava bean, casein, and whey proteins in a fermented gel resulted in improved protein efficiency and protein retention as well as muscle mass gain in young rats. This highprotein-content fava bean-dairy fermented gel could be proposed in pathophysiological situations involving body protein loss.

\section{ACKNOWLEDGMENTS}

This work is part of the "VEGAGE" project, which gets funding from Institut Carnot-Qualiment (France), and received financial support from the European Regional Development Fund and the Bourgogne-FrancheComté (France) regional council. The authors are very grateful to Alexandre Berry, Philippe Lhoste, Phillipe Denis, and Christophe Delhomme (INRA, Clermont Auvergne, France) for their technical assistance and Julien Hermet (INRA, Clermont Auvergne, France) for his welcome and technical support. The authors declare no conflict of interest.

\section{REFERENCES}

Akin, Z., and T. Ozcan. 2017. Functional properties of fermented milk produced with plant proteins. Lebensm. Wiss. Technol. 86:25-30.

Aliya, S., and P. Geervani. 1981. An assessment of the protein quality and vitamin B content of commonly used fermented products of legumes and millets. J. Sci. Food Agric. 32:837-842. https://doi .org/10.1002/jsfa.2740320814.

Alm, L. 1982. Effects of fermentation on curd size and digestibility of milk proteins in vitro of Swedish fermented milk products. J. Dairy Sci. 65:509-514. https://doi.org/10.3168/jds.S0022-0302(82)82227 -3 .

Alonso, R., G. Grant, G. Frühbeck, and F. Marzo. 2002. Muscle and liver protein metabolism in rats fed raw or heat-treated pea seeds. J. Nutr. Biochem. 13:611-618. https://doi.org/10.1016/S0955 -2863(02)00186-9.

Amice-Quemeneur, N., J.-P. Haluk, J. Hardy, and T. P. Kravtchenko. 1995. Influence of the acidification process on the colloidal stability of acidic milk drinks prepared from reconstituted nonfat dry milk. J. Dairy Sci. 78:2683-2690. https://doi.org/10.3168/jds .S0022-0302(95)76899-0.

Anthony, J. C., T. G. Anthony, and D. K. Layman. 1999. Leucine supplementation enhances skeletal muscle recovery in rats following exercise. J. Nutr. 129:1102-1106.

AOAC International. 1995. Official Methods of Analysis. 16th ed. AOAC International, Arlington, VA.

Azim, Z., M. Corredig, M. Koxholt, and M. Alexander. 2010. Sol gel transitions during acid gelation of milk containing modified waxy maize starch. Differences between chemical and bacterial acidification measured using rheological and spectroscopic techniques. Int. Dairy J. 20:785-791. https://doi.org/10.1016/j.idairyj.2010.04 .004 .

Bailey, C. J., and D. Boulter. 1972. The structure of vicilin of Vicia faba. Phytochemistry 11:59-64. https://doi.org/10.1016/S0031 -9422(00)89967-7.

Beliciu, C. M., and C. I. Moraru. 2013. Physico-chemical changes in heat treated micellar casein-soy protein mixtures. Lebensm. Wiss. Technol. 54:469-476. https://doi.org/10.1016/j.lwt.2013.06.013.

Boirie, Y., M. Dangin, P. Gachon, M. P. Vasson, J. L. Maubois, and B. Beaufrère. 1997. Slow and fast dietary proteins differently modulate postprandial protein accretion. Proc. Natl. Acad. Sci. USA 94:14930-14935.

Borack, M. S., P. T. Reidy, S. H. Husaini, M. M. Markofski, R. R. Deer, A. B. Richison, B. S. Lambert, M. B. Cope, R. Mukherjea, K. Jennings, E. Volpi, and B. B. Rasmussen. 2016. Soy-dairy protein blend or whey protein isolate ingestion induces similar postexercise muscle mechanistic target of rapamycin complex 1 signaling and protein synthesis responses in older men. J. Nutr. 146:2468-2475. https://doi.org/10.3945/jn.116.231159.

Boye, J., F. Zare, and A. Pletch. 2010. Pulse proteins: Processing, characterization, functional properties and applications in food and feed. Food Res. Int. 43:414-431. https://doi.org/10.1016/j .foodres.2009.09.003.

Cayot, P., and D. Lorient. 1998. Structure et Technofonctions des Protéines du Lait. Tec \& Doc, Lavoisier, Arilait Recherche, Paris.

Chandan, R. C. 2006. History and consumption trends. Pages 3-17 in Manufacturing Yogurt and Fermented Milks. R. C. Chandan, ed. Blackwell, Ames, IA.

Chandra-Hioe, M. V., C. H. M. Wong, and J. Arcot. 2016. The potential use of fermented chickpea and faba bean flour as food ingredients. Plant Foods Hum. Nutr. 71:90-95. https://doi.org/10.1007/ s11130-016-0532-y.

Chihi, M.-L., J. Mession, N. Sok, and R. Saurel. 2016. Heat-induced soluble protein aggregates from mixed pea globulins and ß-lactoglobulin. J. Agric. Food Chem. 64:2780-2791. https://doi .org/10.1021/acs.jafc.6b00087.

Coda, R., L. Melama, C. G. Rizzello, J. A. Curiel, J. Sibakov, U. Holopainen, M. Pulkkinen, and N. Sozer. 2015. Effect of air classification and fermentation by Lactobacillus plantarum VTT E-133328 on faba bean (Vicia faba L.) flour nutritional properties. Int. J. Food Microbiol. 193:34-42. https://doi.org/10.1016/j.ijfoodmicro .2014.10.012.

Dangin, M., Y. Boirie, C. Garcia-Rodenas, P. Gachon, J. Fauquant, P. Callier, O. Ballèvre, and B. Beaufrère. 2001. The digestion rate of protein is an independent regulating factor of postprandial protein retention. Am. J. Physiol. Endocrinol. Metab. 280:E340-E348.

Dangin, M., Y. Boirie, C. Guillet, and B. Beaufrère. 2002. Influence of the protein digestion rate on protein turnover in young and elderly subjects. J. Nutr. 132:3228S-3233S.

Dangin, M., C. Guillet, C. Garcia-Rodenas, P. Gachon, C. BouteloupDemange, K. Reiffers-Magnani, J. Fauquant, O. Ballèvre, and B. Beaufrère. 2003. The rate of protein digestion affects protein gain differently during aging in humans. J. Physiol. 549:635-644. https: //doi.org/10.1113/jphysiol.2002.036897.

Dardevet, D., C. Sornet, G. Bayle, J. Prugnaud, C. Pouyet, and J. Grizard. 2002. Postprandial stimulation of muscle protein synthesis in old rats can be restored by a leucine-supplemented meal. J. Nutr. 132:95-100.

Derbyshire, E., D. J. Wright, and D. Boulter. 1976. Legumin and vicilin, storage proteins of legume seeds. Phytochemistry 15:3-24. https://doi.org/10.1016/S0031-9422(00)89046-9.

Di Cagno, R., M. De Angelis, P. Lavermicocca, M. de Vincenzi, C. Giovannini, M. Faccia, and M. Gobbetti. 2002. Proteolysis by sourdough lactic acid bacteria: Effects on wheat flour protein fractions and gliadin peptides involved in human cereal intolerance. Appl. Environ. Microbiol. 68:623-633. https://doi.org/10.1128/ AEM.68.2.623-633.2002.

Donato, L., and F. Guyomarc'h. 2009. Formation and properties of the whey protein/kappa-casein complexes in heated skim milk-A 
review. Dairy Sci. Technol. 89:3-29. https://doi.org/10.1051/dst: 2008033.

Dumas, A. 1962. Stickstoffbestimmung nach Dumas. Die Praxis des org. Chemikers. (N-determination according to Dumas). 41st ed. Schrag, Nürnberg, Germany.

Duranti, M., and A. Scarafoni. 1999. Modification of storage protein content and quality in legume seeds. J. New Seeds 1:17-35. https: //doi.org/10.1300/J153v01n01_03.

Eskin, N. A. M., and H. M. Henderson. 1974. Lipoxygenase in Vicia faba minor. Phytochemistry 13:2713-2716. https://doi.org/10 1016/0031-9422(74)80228-1.

European Commission. 2009. Commission Regulation (EC) No 152/2009 of 27 January 2009 laying down the methods of sampling and analysis for the official control of feed. European Commission, Brussels, Belgium.

FAO (Food and Agriculture Organization of the United Nations). 2013. Statistical yearbook. Accessed Mar. 15, 2017. http://www .fao.org/docrep/018/i3107e/i3107e.pdf.

Favier, J. C. 1987. Composition du yaourt. Cah. Nutr. Diét. 22:373379

Ghosh, K., and A. K. Ray. 2017. Aquafeed formulation using plant feedstuffs: Prospective application of fish-gut microorganisms and microbial biotechnology. Pages 109-144 in Soft Chemistry and Food Fermentation. Vol. 3. A. M. Grumezescu and A. M. Holban, ed. Academic Press, London, UK.

Grygorczyk, A. 2012. A novel approach to structure generation for texture improvement in a soymilk-dairy gel. PhD Thesis. Guelph Univ., Guelph, ON, Canada.

Gryson, C., S. Walrand, C. Giraudet, P. Rousset, C. Migné, C. Bonhomme, P. Le Ruyet, and Y. Boirie. 2014. "Fast proteins" with a unique essential amino acid content as an optimal nutrition in the elderly: Growing evidence. Clin. Nutr. 33:642-648. https://doi .org/10.1016/j.clnu.2013.09.004.

Gueguen, J. 1983. Legume seed protein extraction, processing, and end product characteristics. Plant Foods Hum. Nutr. 32:267-303. https://doi.org/10.1007/BF01091191.

Heger, J., and Z. Frydrych. 1985. Efficiency of utilization of essential amino acids in growing rats at different levels of intake. Br. J. Nutr. 54:499-508

Ihekoronye, A. I. 1981. A rapid enzymatic and chromatographic predictive model for the in vivo rat-based protein efficiency ratio. PhD Thesis. Missouri Univ., Columbia.

ISO. 2013. Cereals and pulses. Determination of the nitrogen content and calculation of the crude protein content-Kjeldahl method (ISO 20483:2013). International Organization for Standardization, Geneva, Switzerland.

Koopman, R., N. Crombach, A. P. Gijsen, S. Walrand, J. Fauquant, A. K. Kies, S. Lemosquet, W. H. M. Saris, Y. Boirie, and L. J. C. van Loon. 2009. Ingestion of a protein hydrolysate is accompanied by an accelerated in vivo digestion and absorption rate when compared with its intact protein. Am. J. Clin. Nutr. 90:106-115. https: //doi.org/10.3945/ajcn.2009.27474.

Kopf-Bolanz, K. A., F. Schwander, M. Gijs, G. Vergères, R. Portmann, and L. Egger. 2014. Impact of milk processing on the generation of peptides during digestion. Int. Dairy J. 35:130-138. https://doi .org/10.1016/j.idairyj.2013.10.012.

Laemmli, U. K. 1970. Cleavage of structural proteins during the assembly of the head of bacteriophage T4. Nature 227:680-685.

Laligant, A., M.-H. Famelart, G. Brulé, M. Piot, and D. Paquet. 2003. Fermentation by lactic acid bacteria at two temperatures of preheated reconstituted milk. I-Behaviour of proteins and minerals. Lait 83:181-192. https://doi.org/10.1051/lait:2003008.

Lee, H., B. A. Friend, and K. M. Shahani. 1988. Factors affecting the protein quality of yogurt and acidophilus milk. J. Dairy Sci. 71:3203-3213. https://doi.org/10.3168/jds.S0022-0302(88)79925 -7 .

Li, Q., Y. Xia, L. Zhou, and J. Xie. 2013. Evaluation of the rheological, textural, microstructural and sensory properties of soy cheese spreads. Food Bioprod. Processing 91:429-439. https://doi.org/10 $.1016 /$ j.fbp.2013.03.001.
Liene, S., and M.-B. Sandra. 2016. The characteristics of extruded faba beans (Vicia faba L.). Raksti 36:42-48. https://doi.org/10 .1515/plua-2016-0013.

Lucey, J. A., M. Tamehana, H. Singh, and P. A. Munro. 1998. A comparison of the formation, rheological properties and microstructure of acid skim milk gels made with a bacterial culture or glucono- $\delta$ lactone. Food Res. Int. 31:147-155. https://doi.org/10.1016/S0963 -9969(98)00075-1.

Martínez, J. A., M. Goena, S. Santidrián, and J. Larralde. 1987. Response of muscle, liver and whole-body protein turnover to two different sources of protein in growing rats. Ann. Nutr. Metab. $31: 146-153$.

Mater, D. D. G., L. Bretigny, O. Firmesse, M.-J. Flores, A. Mogenet, J.-L. Bresson, and G. Corthier. 2005. Streptococcus thermophilus and Lactobacillus delbrueckii ssp. bulgaricus survive gastrointestinal transit of healthy volunteers consuming yogurt. FEMS Microbiol. Lett. 250:185-187.

Mession, J.-L., S. Roustel, and R. Saurel. 2017a. Interactions in casein micelle-pea protein system (part I): Heat-induced denaturation and aggregation. Food Hydrocoll. 67:229-242. https://doi.org/10 $.1016 /$ j.foodhyd.2015.12.015.

Mession, J.-L., S. Roustel, and R. Saurel. 2017b. Interactions in casein micelle-pea protein system (part II): Mixture acid gelation with glucono- $\delta$-lactone. Food Hydrocoll. 73:344-357. https://doi.org/10 .1016/j.foodhyd.2017.06.029.

Miller, G. L. 1959. Use of dinitrosalicylic acid reagent for determination of reducing sugar. Anal. Chem. 31:426-428.

Nyachoti, C. M., C. F. M. de Lange, B. W. McBride, and H. Schulze. 1997. Significance of endogenous gut nitrogen losses in the nutrition of growing pigs: A review. Can. J. Anim. Sci. 77:149-163. https://doi.org/10.4141/A96-044.

Paul, G. L. 2009. The rationale for consuming protein blends in sports nutrition. J. Am. Coll. Nutr. 28(Suppl.):464S-472S

Proll, J., K. J. Petzke, I. E. Ezeagu, and C. C. Metges. 1998. Low nutritional quality of unconventional tropical crop seeds in rats. J. Nutr. 128:2014-2022.

Reidy, P. T., D. K. Walker, J. M. Dickinson, D. M. Gundermann, M. J. Drummond, K. L. Timmerman, C. S. Fry, M. S. Borack, M. B. Cope, R. Mukherjea, K. Jennings, E. Volpi, and B. B. Rasmussen. 2013. Protein blend ingestion following resistance exercise promotes human muscle protein synthesis. J. Nutr. 143:410-416. https://doi.org/10.3945/jn.112.168021.

Rieu, I., C. Sornet, G. Bayle, J. Prugnaud, C. Pouyet, M. Balage, I Papet, J. Grizard, and D. Dardevet. 2003. Leucine-supplemented meal feeding for ten days beneficially affects postprandial muscle protein synthesis in old rats. J. Nutr. 133:1198-1205.

Rizzello, C. G., M. Verni, H. Koivula, M. Montemurro, L. Seppa, M. Kemell, K. Katina, R. Coda, and M. Gobbetti. 2017. Influence of fermented faba bean flour on the nutritional, technological and sensory quality of fortified pasta. Food Funct. 8:860-871. https:// doi.org/10.1039/c6fo01808d.

Roesch, R. R., and M. Corredig. 2005. Heat-induced soy-whey proteins interactions: Formation of soluble and insoluble protein complexes. J. Agric. Food Chem. 53:3476-3482. https://doi.org/10.1021/ jf048870d

Roesch, R. R., and M. Corredig. 2006. Study of the effect of soy proteins on the acid-induced gelation of casein micelles. J. Agric. Food Chem. 54:8236-8243. https://doi.org/10.1021/jf060875i.

Sfakianakis, P., and C. Tzia. 2014. Conventional and innovative processing of milk for yogurt manufacture; Development of texture and flavor: A review. Foods 3:176-193. https://doi.org/10.3390/ foods 3010176 .

Sikalidis, A. K., and M. H. Stipanuk. 2010. Growing rats respond to a sulfur amino acid-deficient diet by phosphorylation of the $\alpha$ subunit of eukaryotic initiation factor 2 heterotrimeric complex and induction of adaptive components of the integrated stress response. J. Nutr. 140:1080-1085. https://doi.org/10.3945/jn.109 .120428 .

Torres, A., J. Frias, M. Granito, and C. Vidal-Valverde. 2006. Fermented pigeon pea (Cajanus cajan) ingredients in pasta products. 
J. Agric. Food Chem. 54:6685-6691. https://doi.org/10.1021/ jf0606095.

Vlahopoulou, I., and A. E. Bell. 1995. Preliminary studies on the gelation processes of fermented and GDL-acidified bovine and caprine milk systems. Int. J. Dairy Technol. 48:112-116. https://doi.org/ 10.1111/j.1471-0307.1995.tb02479.x.

Wall, B. T., H. M. Hamer, A. de Lange, A. Kiskini, B. B. L. Groen, J. M. G. Senden, A. P. Gijsen, L. B. Verdijk, and L. J. C. van Loon. 2013. Leucine co-ingestion improves post-prandial muscle protein accretion in elderly men. Clin. Nutr. 32:412-419. https://doi.org/ 10.1016/j.clnu.2012.09.002.

Wong, D., T. Vasanthan, and L. Ozimek. 2013. Synergistic enhancement in the co-gelation of salt-soluble pea proteins and whey proteins. Food Chem. 141:3913-3919. https://doi.org/10.1016/j .foodchem.2013.05.082.

Wright, D. J., and D. Boulter. 1974. Purification and subunit structure of legumin of Vicia faba L. (broad bean). Biochem. J. 141:413-418.

Yousseef, M., C. Lafarge, D. Valentin, S. Lubbers, and F. Husson. 2016. Fermentation of cow milk and/or pea milk mixtures by different starter cultures: Physico-chemical and sensorial properties. Lebensm. Wiss. Technol. 69:430-437. https://doi.org/10.1016/j .lwt.2016.01.060.
Zare, F., J. I. Boye, V. Orsat, C. P. Champagne, and B. K. Simpson. 2011. Microbial, physical and sensory properties of yogurt supplemented with lentil flour. Food Res. Int. 44:2482-2488. https://doi .org/10.1016/j.foodres.2011.01.002

Zare, F., C. P. Champagne, B. K. Simpson, V. Orsat, and J. I. Boye 2012a. Effect of the addition of pulse ingredients to milk on acid production by probiotic and yoghurt starter cultures. Lebensm. Wiss. Technol. 45:155-160. https://doi.org/10.1016/j.lwt.2011.08 .012 .

Zare, F., V. Orsat, C. P. Champagne, B. K. Simpson, and J. I. Boye. 2012b. Microbial and physical properties of probiotic fermented milk supplemented with lentil flour. J. Food Res. 1:94. https://doi .org/10.5539/jfr.v1n1p94.

Zheng, B.-A., Y. Matsumura, and T. Mori. 1991. Thermal gelation mechanism of legumin from broad beans. J. Food Sci. 56:722-725. https://doi.org/10.1111/j.1365-2621.1991.tb05366.x.

Zheng, B.-A., Y. Matsumura, and T. Mori. 1992. Molecular forces in thermal association-dissociation and gelation of legumin from broad beans. J. Food Sci. 57:423-426. https://doi.org/10.1111/j .1365-2621.1992.tb05508.x. 